ROCZNIKI HUMANISTYCZNE

Volume 67, issue $2-2019$

SELECTED PAPERS IN ENGLISH

DOI: http://dx.doi.org/10.18290/rh.2019.68.2-7en

JAN PTAK

\title{
INSCRIPTIONS ON MILITARY FLAGS IN POLAND: AN ATTEMPT AT FORMING A TYPOLOGY
}

The use of flags has been common practice in the Polish military since Medieval times. These objects have played an unusually important role in the organization of military units and in commanding them on the battlefield. They have been identification marks of defined military formations or tactical units. They were the attribute of a superior power (monarch, state) that armed forces were subordinate to, and also symbolized certain ideological values - patriotic or religious. ${ }^{1}$ In all these aspects the significance of flags could result from even their very presence; apart from this gestures made as part of ceremonial behaviors were also important. A significant role, both in the practical, ideological and symbolical spheres, has always been played by the construction of these objects, and by what their contents were-like the shapes and colors of the flag sheets, images and inscriptions. Most often they were composed in a planned way, so that they could form a definite whole. This is why analyses of inscriptions on flags have to be accompanied by the awareness usually they are not an autonomous element, although the element is easy to separate in the formal aspect. Inscriptions were placed not only on sheets, but also on the head of flags, nails hammered into the flagpoles and banderoles attached under the heads.

Dr. hab. JAN PTAK, Prof at KUL — John Paul II Catholic University of Lublin, Institute of History, Department of Medieval History; address for correspondence: Al. Racławickie 14, 20 950 Lublin; e-mail: janptak@interia.pl.

The Polish version of the article was published in Roczniki Humanistyczne 56 (2008), issue 2.

${ }^{1}$ The term "flag" usually denotes an object consisting of a flagpole and a piece of fabric attached to it; in Polish the fabric is also called "płat" (sheet). In modern times the word "sztandar" (standard) also appeared; initially, it denoted the combat sign of the cavalry, and then a military flag in general. In modern literature flags, standards, banners and other similar objects are sometimes called "vexilla." 
It may be supposed that until the close of the Middle Ages flags used in Poland for military aims did not carry any inscriptions because there are no mentions of them in the sources. For example, Jan Długosz does not write anything about it, although he precisely describes all flags carried by King Władysław Jagiełło's and Grand Duke Vytautas's forces fighting at Grunwald, as well as those carried by their opponents. From his account it seems that only heraldic badges were placed on these objects. ${ }^{2}$

It was only in modern times that inscriptions became a component of Polish armed forces' vexilla. In the body of these inscriptions an extraordinary wealth of content and a great variety of wordings can easily be seen. This is why in vexillological studies finding at least the most general regularities that have occurred in this sphere would seem useful. An attempt at grouping flag inscriptions, depending on their contents, into several separate categories could be a good start towards this goal. And this is the aim of this review of them in the present study.

In the classification, the first group that should be distinguished are those that pointed to the owner of the flag. Usually it was the state whose sovereignty was personified by the ruler; sometimes another organizational or territorial unit, a person or an institution played this role. In numerous cases such inscriptions were to make possible the identification of the unit to which the flag directly belonged. Hence all inscriptions in this group may be called proprietary.

In the epoch before the partitions they referred to the monarchs in whose name armed formations were created and then acted. The oldest Polish vexilla with inscriptions that have been preserved and may be included in the category we are discussing date back to the epoch of the House of Vasa. In the Polish Army Museum there are two flags dating from the times of Sigismund III Vasa with the Pahonia coat of arms presented on the sheet, around which there is the inscription: SIGISMUNDUS III DEI GRATIA REX POLONIAE MAGNUS DVX LITVANIAE, ${ }^{3}$ and beside it, in the surround there are the forms of twa rosettes, on one of which there is the word GRODZIENSKA, and on the other SLONIMSKA. ${ }^{4}$ Moreover, in the collection of the Historical and Ethnograph-

\footnotetext{
${ }^{2}$ Joannis Dlugossi Annales seu cronicae Incliti Regni Poloniae, Liber 10 et 11: 1406-1412, Varsaviae 1997, pp. 88-98.

${ }^{3}$ In the present work the quoted inscriptions from the flags are always printed in capital letters, although originally inscriptions in miniscule also happened, albeit not very often.

${ }^{4}$ Muzeum Wojska Polskiego w Warszawie. Katalog zbiorów. Wiek XVII [The Polish Army Museum in Warsaw: A Catalogue of the Collections. The $17^{\text {th }}$ Century], ed. Zofia Stefańska and Zygmunt Gamski (Warszawa: Wydawnictwo Ministerstwa Obrony Narodowej, 1968), items 298-299.
} 
ical Museum in Vilnius another such flag is kept that differs from those described above only in the shape of the sheet and the inscription TROCKA in the rosette. ${ }^{5}$ All of these objects were probably created in the second decade of the $17^{\text {th }}$ century as military standards of the armed units of "county soldiers," first formed in Poland in 1613 as a form of additional conscription. ${ }^{6}$ The inscriptions in the rosettes surely point to the territories where the units were formed, that is the Grodno and Słonim Counties, and the Trakai Voivodeship (or possibly County). ${ }^{7}$

Over time, the names of the successive members of the Vasa Dynasty appeared on the military vexilla. One of the royal flags captured by the Swedes and kept in the Army Museum in Stockholm has the date 1636 and the inscription: LADISLAUS IV REX POL[oniae] ET SUECIAE beside the Polish and Swedish coats of arms. ${ }^{8}$ And on the red flag with the White Eagle that John II Casimir Vasa's emissaries took to Bohdan Khmelnytsky in February 1649 there was - according to Wojciech Miaskowski's account - the inscription JOANNES CASIMIRUS REX. Handing it to Khmelnytsky along with other insignia was to be a symbol of appointing him to the office of the Cossack Hetman by the authorities of the Republic of Poland. ${ }^{9}$

\footnotetext{
${ }^{5}$ Stefan K. KuCZYŃski, Polskie herby ziemskie. Geneza, treści, funkcje [Polish District Coatsof-Arms: The Origin, Contents, Functions] (Warszawa: Wydawnictwo Naukowe PWN, 1993), 190 and Fig. 187.

${ }^{6}$ Ibid., 190 and footnote 57 in p. 221.

${ }^{7}$ Trakai was the capital of both the Voivodeship and the County; see Zygmunt GLoGer, Geografia historyczna dawnej Polski [Historical Geography of the Old Poland] (Kraków: Spółka Wydawnicza Polska, 1903), 285; Stefan K. Kuczyński (Polskie herby ziemskie, 190) calls this flag "a Voivodeship one", but since there was a separate flag for Grodno County that was part of the Trakai Voivodeship, it cannot be ruled out that each County in this Voivodeship, including Trakai County, formed a separate unit having its own military standard.

${ }^{8}$ Waldemar GRABOWSKI, "Polskie choragwie z XVI-XVIII wieku w zbiorach ikonograficznych Armemuseum w Sztokholmie [Polish Flags of the $16^{\text {th }}-18^{\text {th }}$ Centuries in the Iconographic Collection of the Armemuseum in Stockholm]," Dawna Broń i Barwa 16 (2001), No. 23: 16 and Fig. 3.

${ }^{9}$ Wojciech MIASKOWSKI, "Diariusz drogi do wojska zaporoskiego p. wojewody bracławskiego Kisiela i pp. podkomorzego lwowskiego Miaskowskiego, chorążego nowogrodzkiego Mikołaja Kisiela, podczaszego bracławskiego Jakoba Zielińskiego i p. Smarowskiego sekretarza komissarzow i kollegow jego [The Diary of the Journey to Mr Bratslav Voivode Kisiel's Zaporizhia Unit and Messrs Lvov Chamberlain Miaskowski, Novgorod Standard-Bearer Mikołaj Kisiel, Bratslav Cup-Bearer Jakob Zieliński and Mr Secretary Smarowski and His Collegues]," in Zbiór pamiętników historycznych o dawnej Polszcze z rękopismow, tudzież dzieł w różnych językach o Polszcze wydanych oraz z listami oryginalnemi królów i znakomitych ludzi $w$ kraju naszym [A Collection of Historical Memoirs About the Old Poland from Manuscripts, and Works Published in Various Languages about Poland as well as Genuine Letters by Kings and Brilliant People in Our Country], by Julian Ursyn Niemcewicz, vol. 4 (Warszawa, [s.d.]), 264.
} 
Sometimes the names and titles of the rulers were rendered by means of monographs consisting of a set of individual letters. The company flags from the time of the "Swedish Flood" (the Second Northern War) kept in Stockholm are an example here; on the right side of the sheets they have multifield coats of arms surrounded by the initials ICRPETS that may be read as "Ioannes Casimirus Rex Poloniae et Sveciae". ${ }^{10}$ In the $18^{\text {th }}$ century, putting names in the form of monograms on royal vexilla became common practice. In the times of the House of Wettin on the infantry's and cavalry's flags (including dragoons' cornettes) the monogram AR appeared that stood for the words "Augustus Rex". ${ }^{11}$ An infantry flag with such initials on the four corners of the sheet is seen in Mock's painting showing the so-called "kampament" (display) of Polish and Saxon troops that took place in the vicinity of Warsaw in $1732 .^{12}$

In turn, on the dragoons' cornette dating back to the times of Stanisław Leszczyński, in the corners of the sheet the letters SR (Stanislaus Rex) are shown. ${ }^{13}$ The habit of placing royal monograms on military standards also continued in the times of Stanisław August. On the dragoons' cornettes of 1764, under the King's crown there are the letters SPRP that doubtless may be read as "Stanislaus Poniatowski Rex Poloniae". ${ }^{14}$ However, at the times of this king's rule the most popular monogram was SAR (Stanislaus Augustus Rex) placed under the crown; it is seen in many preserved flags, banners and cornettes. On one of the flags, the same monogram is preserved not only on the very sheet, but also inside the openwork truck made of bronze, fastened to the flagpole. ${ }^{15}$

In the Old Polish period inscriptions on military vexilla referred not only to monarchs but also to other people. Usually they were military commanders, dignitaries forming military units, or possibly owners of court formations. Among the items dating from the $17^{\text {th }}$ and $18^{\text {th }}$ centuries kept in the Polish Army Museum there are many examples illustrating this phenomenon.

\footnotetext{
${ }^{10}$ GRABOwSKI, "Polskie choragwie z XVI-XVIII wieku," 14 and Table IV.

${ }^{11}$ Muzeum Wojska Polskiego w Warszawie. Katalog zbiorów. Wiek XVIII [The Polish Army Museum in Warsaw: A Catalogue of the Collections. The $18^{\text {th }}$ Century], ed. Zofia Stefańska, Jan Benda, Alfred Funkiewicz, Maria Rohozińska, and Józef Zalewski (Warszawa: Wydawnictwo Ministerstwa Obrony Narodowej, 1960), 144-145 (items 312-314).

${ }^{12}$ Bronisław GembarzewsKI, Żotnierz polski. Ubiór, uzbrojenie i oporzqdzenie [The Polish Soldier: Dress, Weaponry and Equipment], vol. 2: Od 1697 do 1794 roku [From 1697 Till 1794] (Warszawa: Wydawnictwo Ministerstwa Obrony Narodowej, 1962), 118-119.

${ }^{13}$ Muzeum Wojska Polskiego w Warszawie. Katalog zbiorów. Wiek XVIII, 145 (item 315).

${ }^{14}$ Ibid., 148 (item 323).

${ }^{15}$ Ibid., 147-148, 151-156 (items 322, 324-325, 332-345).
} 
They include the military standard of Jan Sławiński's Cossack flag that on the green sheet has the image of St Michael the Archangel, beside it there is the Knight's Cross and Sławiński's coat of arms in the cartouche, surrounded by the letters I[an] S[ławiński] M[iecznik - Sword-bearer] S[tarodubski] A[nno] D[omini] 1649. ${ }^{16}$ On Stanisław Denhof's flag (Denhof was the Lithuanian Field Hetman) of 1718, on the reverse side in the corners of the sheet there are golden monograms: S[tanislaus] D[enhof] V[ice] D[ux] G[eneralis $].{ }^{17}$ Similarly, two flags of the formations commanded by Antoni Pociej, a supporter of King Stanisław Leszczyński and the Lithuanian General Regimentarz (which replaced Hetman) in 1734, in their corners have the monograms: A[ntoni] P[ociej] R[egimentarz] G[eneralny]. One of these is considered to be the flag of the Lithuanian Artillery, as it has a picture of a cannon, two barrels and cannonballs. ${ }^{18}$ The court flag from 1743 of August Czartoryski, the Ruthenian Voivode and commander of the Crown Infantry Guards, has the monograms AC under the prince's mitre on its four corners. ${ }^{19}$

Vexilla used by members of armed confederations that were frequently formed in the $18^{\text {th }}$ century also contained inscriptions referring to persons or groups of people playing leading roles in those undertakings. From the times of the Dzikowska Confederation formed under the leadership of the Starost of Jasło Adam Tarło comes his flag, the Starost of Gostynin's "serious formation" (Hussars or armored knights) that has a cross with the letters PG (powiat gostyński; the County of Gostynin) embroidered in the middle, and in the corner the Tarło family's coat of arms of Topór and the letters: ATSGRPGP. This abbreviation was interpreted as meaning "Adam Tarło Starosta Gostyński Regimentarz Generalny Powiatu"20, or, in another version, (interpreting the penultimate letter as $\mathrm{C}$ instead of $\mathrm{G}$ ): “Adam Tarło Starosta Gostyński Rotmistrz Chorągwi Pancernej" (Starost of Gostyin Cavalry, Cavalry Captain of an Armored Company). ${ }^{21}$ At the time of the Confederation of Bar his coat of arms were on the flag of the Podlaskie Voivode-

\footnotetext{
${ }^{16}$ Muzeum Wojska Polskiego w Warszawie. Katalog zbiorów. Wiek XVIII, 195 without the explanation of the monogram. The full contents of the inscription is quoted by Richard BRZEZIŃSKI, Polish Armies 1569-1696 (1), Men at Arms Series (London: Osprey Publishing, 1987), 47.

${ }^{17}$ Muzeum Wojska Polskiego w Warszawie. Katalog zbiorów. Wiek XVIII, 143 (item 309); GEMBARZEWSKI, Żotnierz polski, 120-123.

${ }^{18}$ Muzeum Wojska Polskiego w Warszawie. Katalog zbiorów. Wiek XVIII, 143-144, 146 (items 310, 318)

${ }^{19}$ Ibid., 147 (item 320).

${ }^{20}$ Ibid., 144 (item 311) in the description the terms "gostyński" and "goszczyński" are used interchangeably.

${ }^{21}$ GembarZEwski, Żotnierz polski, 42-43.
} 
ship on the right-hand side: the Orzeł (Eagle) and Pogon (Pahonia) under a crown, and under it a banderole with the abbreviation of the name of that territory: PAL[atinatus] POD[lachiae]. ${ }^{22}$

The vexilla of the Polish army units formed in the post-partition epoch were often provided with inscriptions that included their names. As an example, we may mention the flag that was created by the authorities of the Transpadane Republic in 1797 for the $1^{\text {st }}$ Fusilier Battalion formed as part of the Polish Legions. On its sheet, on the main side was placed the inscription: LEGIONE POLACCA AUSILIARI DI LOMBARDIA, and in the lower corners FUCILIERI. 1o BATAGLIONE. Polish inscriptions on the reverse side have the same contents: LEGION POLSKI AUXILIARNY LOMBARDYI / / FISYLIERY 1.ZCY [! - the wrong spelling] BATALION (The Polish Auxiliary Legion of Lombardy // Fusiliers of the $1^{\text {st }}$ Battalion). ${ }^{23}$ Another flag, probably designed for the cavalry unit of the Legions that is known only from its image, had inscriptions in French: REPUBLIQUE FRANÇAISE - LEGION POLONAISE D'ITALIE. ${ }^{24}$ On the tricolor sheet of the flag of the $1^{\text {st }}$ Infantry Regiment of Legia Nadwiślańska are placed the words: L'EMPEREUR NAPOLÉON AU REGIMENT POLONAIS. A more precise identification of the unit is made possible by the figure " 1 " seen on the table, on which the Imperial golden eagle was placed crowning the flagpole. ${ }^{25}$ Among the relics that are left from the famous Light Cavalry Regiment of the Imperial Guard the colonel's pendant has been preserved, richly covered with inscriptions, among them one in the form of the word WYBAWICIEL (Savior), placed under the initial N, situated against the background of a five-pointed star, that refers to Napoleon, and another one is the sign of the unit: PUŁK LEKKOKONNY-POLSKI-PRZY-BOKU-NAPOLEONAWIELKIEGO (Polish Light Cavalry Regiment at Napoleon the Great's Side) ${ }^{26}$

In the forces of the Duchy of Warsaw the basic elements of the military standards were, besides the sheets, metal eagles that crowned the flagpoles; hence they started being called "eagles". From our point of view it is important that the inscriptions outside the sheet now also appeared on the metal plaques on which the eagle figures were set. An example of such a vexillum

${ }^{22}$ Muzeum Wojska Polskiego w Warszawie. Katalog zbiorów. Wiek XVIII, 149 (item 327).

${ }^{23}$ Bronisław GemBARZEwSKI, Żotnierz polski. Ubiór, uzbrojenie i oporzqdzenie [The Polish Soldier: Dress, Weaponry and Equipment], vol. 3: Od 1797 do 1814 roku [From 1797 Till 1814] (Warszawa: Wydawnictwo Ministerstwa Obrony Narodowej, 1964), Table 4.

${ }^{24}$ Stanisław GEPNER, "Sztandary [Standards]," in Księga jazdy polskiej [The Book of Polish Cavalry], ed. Bronisław Wieniawa-Długoszowski and Stanisław J. Haykowski (Warszawa: Zakłady Graficzne Instytutu Wydawniczego "Biblioteka Polska”, 1938), 243.

${ }^{25}$ GemBARZEWSKI, Żotnierz polski, vol. 3, Table 42.

${ }^{26}$ Ibid., Table 80. 
is the flag of the 1. Mounted Rifles Regiment. Its crown is an eagle on the plaque provided with the inscription WOYSKO (Army) on one side, and POLSKIE (Polish) on the other; and on the sheet, apart from the image of the eagle, there are the words LEGJA 1 (Legion 1) and I. PUŁK LEKKI JAZDY (the $1^{\text {st }}$ Light Cavalry Regiment). Similar contents are found on the flag of the 15. Cavalry Regiment, differing from the one described above in the inscription on the sheet PUŁK XV JAZDY (the $15^{\text {th }}$ Cavalry Regiment). ${ }^{27}$ The flag of the $2^{\text {nd }}$ Infantry Regiment of the Duchy of Warsaw has on its plaque the inscription PUŁK PIECHOTY (Infantry Regiment), and on the sheet, over the image of the White Eagle holding the royal insignia in the claws: LEGIA I, and beneath: PUŁK 2 GI PIECHOTY (the $2^{\text {nd }}$ Infantry Regiment). The words WOYSKO POLSKIE were sometimes also placed on the sheets, an example being the flag of the Headquarters of 1807, which was, according to tradition, made by Barbara Dąbrowska, the wife of Jan Henryk Dąbrowski. ${ }^{28}$

The army of the Polish Kingdom received flags made according to uniform models, defined by regulations. In the infantry, flags of particular regiments differed from one another in color. They did not have inscriptions in full form; only in the corners of the sheets, between the arms of the crosses were royal monograms (the so-called figures) placed: A I or M I, meaning the successive rulers of the state established in 1815: Alexander I and Nicholas I. ${ }^{29}$ On the flags that the cavalry received in 1829 , on the sheets under the image of the Eagle were the regiment signs in the form of initials, eg. P[ułk] S[trzelców] K[onnych] G[wardii] (the Mounted Rifle Regiment of the Guard), P[ułk] S[trzelców] K[onnych] N[astępcy] T[ronu] No 1 (the Mounted Rifle Regiment of the Heir to the Throne Nr 1), P[ułk] 2I U[łanów] (the $2^{\text {nd }}$ Uhlan Regiment), P[ułk] 3CI S[trzelców] K[onnych] (the $3^{\text {rd }}$ Mounted Rifle Regiment), P[ułk] U[łanów] X[Księcia] O[rańskiego] Nr 1 (the Uhlan Regiment of the Prince of Orange Nr 1). ${ }^{30}$

During the November Uprising the flags mentioned were not used, even though the royal figures were removed from them. The National Government's resolution passed on $6^{\text {th }}$ February 1831 said that they should be sub-

\footnotetext{
${ }^{27}$ GEPNER, "Sztandary," 244.

${ }^{28}$ Alfred ZnAmiERowski, Stworzony do chwaty [Made for Glory] (Warszawa: Editions Spotkania, 1993), 993, Fig. 267; 185, Fig. 268

${ }^{29}$ BigoszewsKa, Wanda, and Maria Halina SŁoniewskA. "Chorągwie i sztandary z lat 18151831 w zbiorach Muzeum Wojska Polskiego [Flags and Standards of the Years 1815-1831 in the Polish Army Museum Collections]," in Muzealnictwo Wojskowe [Military Museology], vol. 3, ed. Muzeum Wojska Polskiego [Polish Army Museum] (Warszawa: Wydawnictwo Ministerstwa Obrony Narodowej, 1985), 281.

${ }^{30}$ GePner, "Sztandary,” 244; BigoszewsKa and SŁoniewsKa, "Choragwie i sztandary,” 288.
} 
stituted by "Polish Eagles" modeled after the military standards of the Duchy of Warsaw. Like those, on the plaques under the metal eagles they had the inscription WOYSKO POLSKIE, and on the sheets were the images of eagles only. They were made for all the infantry regiments, two for each regiment, which makes 26 altogether. ${ }^{31}$ Among them there was the flag of the $4^{\text {th }}$ Infantry Regiment that is kept in the Polish Army Museum. On one side of the plaque under the eagle there is the inscription PULK 4. PIECHOTY LINIOWEY (the $4^{\text {th }}$ Regiment of Front-Line Infantry), and on the other WOYSKO POLSKIE. ${ }^{32}$ Unfortunately, these vexilla also were not used in action.

On the other hand, the formations that were set up during the uprising received military standards individually; they were often funded by individual people or by local societies. Fairly large freedom and variety is connected with this, as far as the iconographic contents and inscriptions are concerned. The latter ones in many cases also defined the identity of the unit, e.g. the flag of the first regiment of Mazurians on the left-hand side in a circle of laurel and oak branches had the inscription: PÓŁK 1. MAZURÓW (the $1^{\text {st }}$ Mazurian Regiment).$^{33}$ On the flag of the $1^{\text {st }}$ Battalion of the $14^{\text {th }}$ Infantry Regiment on one side there was an eagle and the inscription: PÓŁK 14-STY over the eagle, and under it BATTALION 1-SZY; on the other side was an inscription a little different from this one: PÓŁK 14-STY PIECHOTY LINIOWEJ BATTON 1-SZY (the $14^{\text {th }}$ Regiment of Front-Line Infantry $1^{\text {st }}$ Batt-on). A flag in the form of a "labarum" was the military standard of the $1^{\text {st }}$ Regiment of the Warsaw National Guard; on the top of the flagpole it had an eagle on the plaque with the inscription GWARDYA NARODOWA (National Guard) on one side and PÓ£K 1SZY (the $1^{\text {st }}$ Regiment) on the other; and on the sheet of crimson velvet PÓŁK 1SZY GWARDYI NARODOWEY (the First Regiment of the National Guard) in the laurel wreath. So the inscription identifying the unit was placed here both on the metal plaque and on the fabric. Another preserved flag also dating from that period has inscriptions giving information about its owners both on the sheet: STRZELCY CELNE WOJEWÓDZTW KRAKOWSKIEGO I SANDOMIERSKIEGO (the Riflemen of the Krakowskie and Sandomierskie Voivodeships), and on the wooden plaque that is the base for the metal eagle: STRZELCY CELNE on the one side, and WOYSKO POLSKIE on the other. ${ }^{34}$

On the preserved flags dating from the period of the January Uprising there are few inscriptions referring to the soldiers that used them. The vexillum that has on the reverse side of the sheet the words: STRZELCÓW I KOSSYNIERÓW (Ri-

\footnotetext{
${ }^{31}$ BigoszewsKa and SŁOnIEwSKA, "Chorągwie i sztandary,” 292-293.

${ }^{32}$ Ibid., 283.

${ }^{33}$ GEPNER, "Sztandary," 245.

${ }^{34}$ BigoszewSKa and SŁONIEwSKa, “Chorągwie i sztandary,” 297-299.
} 
flemen's and Scythe-bearing Soldiers') may be counted among them ${ }^{35}$; the inscription rather points to the type of the formation than to a particular organizational unit. On the other hand, the sheet of the flag of the unit formed in February 1863 by Fr. Antoni Mackiewicz, apart from the Eagle wearing a crown, has the inscription: PUŁK PODBRZEŹSKI (the Podbrzezie Regiment), referring to the village Podbrzezie in the Poniewież County, where the unit was formed. ${ }^{36}$

In the battles for Poland's independence and borders in the years 19141921 numerous formations took part; and they had a great variety of military standards. However, in this epoch the inscriptions placed on the flags also gave information about who was using those objects. As an example, we may mentioned the flag with the date 1915 and the inscription: II i III SZWADRON UŁANÓW POLSKICH (the II and III Uhlan Unit), used by the cavalry of the First Brigade of the Legions. ${ }^{37}$ In the Polish Army in France the inscriptions on the flags were the only element allowing identification of the units, since all those objects were made according to one pattern. Their appearance is shown by one of the eight flags that in June 1918 were handed to Polish formations by President E. Poincaré. On the right side of the sheet it has the inscription WOJSKO POLSKIE, and on the left, along with the White Eagle, PIERWSZY PUŁK STRZELCÓW PIESZYCH (the First Regiment of Infantry Riflemen).$^{38}$ In turn, on the flag of the regiment formed in 1918 in Italy and kept in the Polish Army Museum there is the inscription PUŁK FRANCESCO NULLO (the Francesco Nullo Regiment). It is one of seven flags designed for Polish regiments formed in that country at that time, on which (for the first time in history) the persons of their patrons were commemorated in the names of the units. ${ }^{39}$ Similarly, on the main side of the flag that in November 1919 was handed to the First Light Cavalrymen Regiment whose commander was Józef Piłsudski, the name of the unit was placed beside the White Eagle: 1SZY PUŁK SZWOLEŻERÓW JÓZEFA PIŁSUDSKIEGO. ${ }^{40}$

${ }^{35}$ Powstanie styczniowe $w$ zbiorach Muzeum Wojska Polskiego [The January Uprising in the Polish Army Museum Collection], ed. Wanda Bigoszewska and Maria Halina Słoniewska (Warszawa: Wydawnictwo Ministerstwa Obrony Narodowej, 1966), 110-112.

${ }^{36}$ Ibid., 116-117.

${ }^{37}$ GePNER, "Sztandary," 248; Henryk WIELECKI, "Chorągwie i sztandary w zbiorach Muzeum Wojska Polskiego [Flags and Standards in the Polish Army Museum Collection]," in Muzealnictwo Wojskowe [Military Museology], vol. 7, ed. Muzeum Wojska Polskiego [Polish Army Museum] (Warszawa: Wydawnictwo Ministerstwa Obrony Narodowej, 2000), 336.

${ }^{38}$ Lesław KUKAWSKI, "Sztandary [Standards]," in Broń i barwa Wojska Polskiego w roku 1939. (Informator wystawy) [The Polish Army's Weaponry and Colors in 1939. (Exhibition Guide)], Lublin 1993, 19 and Photo 1.

${ }^{39}$ WiELECKI, "Choragwie i sztandary," 338 and Photo on p. 337.

${ }^{40}$ GePNER, "Sztandary," 247 
In the interwar period the appearance of the flags used in the Polish Army was standardized. The identification of the unit that owned the given military standard was made possible by placing four wreaths with the inscribed number of the regiment between the arms of the red cross on the right side of the sheet. To a certain degree the differences in the sizes of the flags (one side of the sheet $=1 \mathrm{~m})$ and standards $(65 \mathrm{~cm})$ allowed the distinguishing of the military standards of infantry and cavalry units having the same numbers. In order to distinguish the flags of infantry regiments from sapper regiments, the latter could also place the emblems of their formation in the wreaths, along with figures. On the flags of military schools instead of figures initials were placed, e.g. S.P. The figures corresponding to the number of the regiment also appeared on the box base, forming, together with the eagle mounted on it, the metal crown of the flagpole. Here also, beside the figures, the letters SAP appear, if they were the flags of sapper units, and S.K. in the case of mounted rifles regiments. ${ }^{41}$

The time of World War II brought about the establishment of more formations of the Polish Army that fought on various fronts both in Poland and abroad. In many cases they received new military standards, uniformly called from 1937 on "standards." Their appearance was usually modeled on the ones from the time before the war, but they were often enriched with new elements, including inscriptions. The standards of formations of the Polish Army fighting in the Near East and North Africa may serve as an example here. The Polish Independent Carpathian Rifle Brigade on the reverse side of the standard that was given to it in 1941 had the monograms of its name in the form of the letters SBSK placed between the arms of the cross. On the left side of the standard of the Officer Legion there is the full name of the formation: LEGIA OFICERSKA W EGIPCIE (the Officer Legion in Egypt). The $5^{\text {th }}$ Kresowa Infantry Division that was part of the Polish II Corps, on $11^{\text {th }}$ November 1943 in Palestine also received a standard that had on the main side of the sheet the Knight's Cross with the inscription: DYWIZJA KRESOWA 1941 on the lower arm. ${ }^{42}$

On the standard of the oldest unit of the so called Polish People's Army, that is The Polish 1st Tadeusz Kościuszko Infantry Division, the monograms of its name ("1DP") placed in wreaths appeared both on the right side on the arms of the red cross, and on the left side between the arms of the white cross.

\footnotetext{
${ }^{41}$ Encyklopedia wojskowa (Military Encyclopedia), vol. 1, ed. Otto Laskowski (Warszawa: Wydawnictwo Towarzystwa Wiedzy Wojskowej i Wojskowego Instytutu Naukowo-Wydawniczego, 1931), 686-687.

${ }^{42}$ Jerzy MURGRABIA, Symbole wojskowe Polskich Sit Zbrojnych na Zachodzie 1939-1945 [Military Symbols of the Polish Armed Forces in the West 1939-1945] (Warszawa: Bellona, 1990), 44.
} 
An unusual solution may be seen on the standards of some other great formations of this army, namely, infantry divisions, artillery brigades and armored units. Apart from the inscriptions stating their names there are abbreviations of the names of the units belonging to the formation. On the standard of the $2^{\text {nd }}$ Warsaw Infantry Division on the right-hand side under the laurel wreath with the image of the patron there is the inscription 2 DYWIZJA PIECHOTY IM. J. H. DĄBROWSKIEGO (the $2^{\text {nd }}$ J. H. Dąbrowski Infantry Division), and on the left-hand side, which at the same time is the main one, in the wreaths between the arms of the cross, are placed the monograms: $4 \mathrm{P}[\mathrm{ułk}] \mathrm{P}$ [iechoty] (the $4^{\text {th }}$ Infantry Regiment), $6 \mathrm{P}$ [ułk] P[iechoty] (the $6^{\text {th }}$. Infantry Regiment) $2 \mathrm{P}[\mathrm{u} k \mathrm{k}] \mathrm{A}$ [rtylerii] L[ekkiej] (the $2^{\text {nd }}$ Light Artillery Regiment). In the same way on, the standard of the $3^{\text {rd }} \mathrm{R}$. Traugutt Infantry Division there are the inscriptions: 7 P.P., 8 P.P., 9 P.P., 3 P. A. L. The military standard of the $1^{\text {st }}$ Józef Bem Warsaw Heavy Artillery Brigade between the arms of the cross has the inscriptions: 3 P[ułk] A[rtylerii] C[iężkiej], 4 P[ułk Artylerii] PANC[ernej], 1 D[ywizjon] M[oździerzy], 1 D[ywizjon] A[rtylerii] $\mathrm{P}$ [rzeciw] - LOT[niczej] (the $3^{\text {rd }}$ Heavy Artillery Regiment, the $4^{\text {th }}$ Armored Artillery Regiment, the $1^{\text {st }}$ Mortar Brigade, the $1^{\text {st }}$ Anti-aircraft Artillery Brigade). On the standard of the $1^{\text {st }}$ Armored Brigade of the Defenders of Westerplatte in these places are the inscriptions: $1 \mathrm{P}[\mathrm{ułk}$ ] CZOŁG[ów], 1 BA [tali] ON ZMOTOR[yzowany] (the $1^{\text {st }}$ Tank Regiment, the $1^{\text {st }}$ Motorized Battalion). ${ }^{43}$

From the point of view of the aspect that is being studied here, the standards of the underground and guerilla formations that fought in the Polish territories during the occupation period are especially interesting. The inscriptions placed on those objects often contain the names of the organization units functioning at that time in the form of cryptonyms. They may be found, for example, on the standard of the District Inspectorate "Rzeszów". On the main side, where the image of the crowned Eagle is placed, there are the words: INSP[ektorat] RTÉC (Insp[ectorate]), and on the reverse, on the horizontal arms of the cross there are the monograms RP, undoubtedly meaning "Republic of Poland". Moreover, over the coats of arms of the towns that were the seats of the district headquarters are placed their cryptonyms: DESER (Dębica); KEFIR (Kolbuszowa); RÓżA (Rzeszów), and only the coat of

\footnotetext{
${ }^{43}$ Wanda BigoszewsKa and Henryk WiewióRA. Sztandary Ludowego Wojska Polskiego 1943-1974 [Standards of the Polish People's Army 1943-1974] (Warszawa: Wydawnictwo Ministerstwa Obrony Narodowej, 1974), 14-20, 37-44, 104-107, 137-140.
} 
arms of Brzozów is not accompanied by a cryptonym. ${ }^{44}$ A different kind of inscriptions appears on the standard of the $5^{\text {th }}$ Home Army (AK) Sub-district of the VI District of Warsaw. On its right-hand side between the arms of the Knight's Cross in the laurel wreaths are placed the monograms: ON (Obrona Narodowa - National Defence), ow (Organizacja Wojskowa "Wilki"Military Organization "Wolves") and U (Unia-Union), that appear again on the ribbon fastened to the flagpole where, additionally, $G$ (Grunwald) and PZP (Polski Związek Powstańczy - Polish Underground Association) are placed. As may be assumed, these monograms refer to the organizations to which the members of the AK (the Home Army) belonged in the $5^{\text {th }}$ Subdistrict covering the center of Praga. The area in which the unit using the standard was geographically situated is pointed to only by the inscription PRAGA placed on the base of the metal eagle crowning the flagpole. ${ }^{45}$

Sometimes on the standards the open, and not hidden, name of the formation occurred, for example the military standard of the sabotage-diversion unit of the AK Skierniewice District had as an inscription on its main side: ARMIA KRAJOWA; ODDZIAE MIASTA SKIERNIEWIC I POWIATU (the Home Army; Skierniewice Town and District Unit). ${ }^{46}$ The standard of the "Ponury"s Concentration of Guerilla Units of the Home Army had on its main side the inscription: KIEDYW ZIEMIA KIELECKA 1943 (Kiedyw, Kielce Region 1943). ${ }^{47}$ Guerilla troops sometimes had on their military standards names referring to the terms used in the regular army whose functions the Home Army was supposed to fulfill. In Jasna Góra a standard is kept that on the left side of the sheet has letters and figures indicating its owner: O[ddział] L[eśny] 6 [kompania] / II [batalionu] / $26 \mathrm{P}[\mathrm{ukku}] \mathrm{P}$ [iechoty] (the Forest Unit of the $6^{\text {th }}$ Company / of the $26^{\text {th }}$ Infantry Regiment). ${ }^{48}$ Among the vexilla kept in that sanctuary attention should be paid to the standard of the Bolesław Chrobry First Armored Regiment formed in Vilnius by a circle coming from the prewar group ONR-Falanga (National-Radical Camp Falanga). It was fairly precisely modeled after the regulation standard from the interwar period. On its main side between the arms of the Knight's Cross four wreaths are placed

\footnotetext{
${ }^{44}$ Marek Ney-Krwawicz, Zbyszko Siemaszko, and Maciej Siemaszko, Bojowe sztandary i proporce Armii Krajowej [The Home Army's Combat Standards and Pennants] (Warszawa: Krajowa Agencja Wydawnicza, 1991), 30-33.

${ }^{45}$ Ibid., $18-21$.

${ }^{46}$ Ibid., 26-27.

${ }^{47}$ Ibid., 52-53; the word "Kedyw" was a cryptonym of "Kierownictwo Dywersji" [the Directorate of Diversion], here it is used in an untypical version derived directly from the abbreviation of the name.

${ }^{48}$ Ibid., 80-82.
} 
with the inscriptions: $1 \mathrm{P}[\mathrm{u} k \mathrm{k}]$ PANC[erny] IMIENIA BOLESŁAWA CHROBREGO (the $1^{\text {st }}$ Bolesław Chrobry Armored Regiment). ${ }^{49}$ Sometimes, because of the very limited content of the inscriptions, after so many years it is difficult to determine the clandestine or guerilla unit the preserved vexilla belonged to. The sheet of a standard brought from the Vilnius region after the war may serve as an example here; beside the Eagle it only has the Roman figure IV. It is possible that it could be the military standard of the Home Army $4^{\text {th }}$ Brigade "Narocz." 50

After World War II several times regulations concerning the appearance of vexilla were enacted in the Polish Army; they also defined the content of the inscriptions that were placed on them. In 1946 new standards came into use, ones having the motifs of the so called Grunwald Cross on both sides of the sheet. On the main side, between the arms of such a cross in laurel wreaths, the abbreviation of the name of the unit was placed, e.g. 1 . $\mathrm{B}$ [erliński] P[ułk] A[rtylerii] L[ekkiej] (the $1^{\text {st }}$ Berlin Light Artillery Regiment). The same inscription is seen on the metal box constituting part of the head of the standard. ${ }^{51}$ More changes in this respect were introduced by the Decree of the Council of State in 1955, according to which the motif of the cross on the sheets of military flags was substituted by four triangles. On the left side the lower red triangle contained the inscription with the name of the unit to which the standard belonged, e.g. 70 PUŁK PIECHOTY (the $70^{\text {th }}$ Infantry Regiment). ${ }^{52}$ The last change introduced in 1993 restored the traditional appearance of standards in the Armed Forces. Thanks to this, the motif of the Knight's Cross returned to the sheet, and between its arms on the main side wreaths appeared again that bordered the name of the unit, or of another organization of the Polish Army, most often specified with the use of figures. ${ }^{53}$

Another, clearly distinguished group, consists of inscriptions that may be called foundations. They contain information about on whose initiative the standard was created, who founded it, made it and gave it to the owner. The data concerning the place and time of making or of handing the object was also given. The abovementioned French language inscription on the flag of the $1^{\text {st }}$ Infantry Regiment of Legia Nadwiślańska speaking about Emperor

\footnotetext{
${ }^{49}$ Marek NeY-Krwawicz, Sztandary i proporce Armii Krajowej [The Home Army's Standards and Pennants] (Warszawa: Semper, 1994), 52.

${ }^{50}$ Ibid., 108.

${ }^{51}$ Bigoszewska and Wiewióra, Sztandary Ludowego Wojska Polskiego, 196-198.

52 Ibid., 206-207.

${ }^{53}$ Numerous specimens of such standards are presented in Jan Szymański and Stanisław Zając's work Nasze sztandary (Kraków: Instytut Teologiczny Księży Misjonarzy, 1998).
} 
Napoleon donating the flag to the Polish formation had partly such a character. ${ }^{54}$ Later, the standard of the Polish Legion fighting in Hungary during the Revolutions of 1848 , founded by the inhabitants of Buda and donated by the sister of Lajos Kossuth, the Hungarian leader, had a ribbon fastened to the flagpole with an inscription immortalizing this fact: A KÕZÕS SZABADSÁGÉRT [for common freedom] RUTTKAY KOSSUTH LUISZA. ${ }^{55}$

Inscriptions speaking about people who supplied troops fighting in the January Uprising with military standards may be found on some preserved vexillological relics from that period. The flag donated by some inhabitants of the town of Kalisz to Edmund Taczanowski's Brigade on $6^{\text {th }}$ August 1863 is one. On it, under the coats of arms of the Eagle and Pahonia there is the sentence WALECZNYM BRACIOM POŚWIĘCAJĄ POLKI IZRAELITKI KALISZ 1863 (Polish-Israeli Women Devote This To Their Valiant Brothers, Kalisz 1863). The abovementioned flag of the "Riflemen and Scythe-bearing Soldiers" also has on its reverse side the inscription PRACA DZIEWIC POLSKICH (the Work of Polish Maidens). A developed dedication was written on the flag for Gen. Ludwik Mierosławski's unit. On the one-sided sheet over the image of the Eagle the date 1863 was placed and the inscription: GENERAŁOWI MIEROSŁAWSKIEMU (To General Mierosławski), and under the coat of arms: MŁODZIEŻ WARSZAWSKA OFIARUJE (the Young People of Warsaw Donate It). ${ }^{56}$

At the time when independence was being regained flags and standards for armed formations, usually connected with their region, were funded by the inhabitants of many Polish towns and lands who memorized this fact on them with the appropriate inscriptions. On the flag of the $1^{\text {st }}$ Brigade of the Legions the following dedication was placed: I BRYGADZIE 1915 PŁOCK (the Town of Płock To the $1^{\text {st }}$ Brigade).$^{57}$ The flag of the $86^{\text {th }}$ Infantry Regiment of Helenów near Mołodeczno looks very interesting from this aspect. It was funded in 1919 by the inhabitants of Minsk (in present Byelorussia), which is indicated by the image of that town's former stamp placed on the left-hand side, with the words: SIGILLUM CIVITATIS MINSCENSIS ANNO 1569. On its both sides the figures 19-19 can be seen, over it the inscription MIASTO MIŃSK 6MU MIŃSKIEMU PUŁKOWI STRZELCÓW (the Town of Minsk To the $6^{\text {th }}$

\footnotetext{
${ }^{54}$ Gembarzewski, Żotnierz polski, vol. 3, Table 42.

${ }^{55}$ Stefan K. KuCZYŃSKI, Stanisław Russocki, and Juliusz Willaume, Godło, barwy i hymn Rzeczypospolitej. Zarys dziejów [The Emblem, Colors and Anthem of the Republic of Poland: An Outline of the History]. $3^{\text {rd }}$ ed. (Warszawa: Wiedza Powszechna, 1978), 178.

${ }^{56}$ These objects were described in the catalogue mentioned above: Powstanie styczniowe w zbiorach Muzeum Wojska Polskiego, 105, 110, 120.

${ }^{57}$ WIELECKI, "Choragwie i sztandary," 335.
} 
Minsk Riflemen Regiment), and under it another one, in the Latin alphabet but in the Byelorussian language: MIESTO MIENSK 6MU MIENSKAMU POŁKU STRALCOU. ${ }^{58}$

The flag of the $11^{\text {th }}$ Marshal Edward Rydz-Śmigły Legion Uhlans Regiment of Ciechanów, funded by Vilnius on the basis of a resolution passed by the Vilnius Municipal Council may serve as another example. On the lefthand side of its sheet there is the Eagle and the Pahonia under the royal crown and the inscription: OBROŃCOM SWOIM WDZIĘCZNE WILNO (Grateful Vilnius To Its Defenders). ${ }^{59}$ On the flagpole of the standard of the $3^{\text {rd }}$ Uhlan Regiment, along with Warsaw's coat of arms, there is the dedication PUŁKOWI 3 UŁANÓW MIASTO STOŁECZNE WARSZAWA (the Capital City of Warsaw To the $3^{\text {rd }}$ Uhlan Regiment) ${ }^{60}$ An inscription of a similar type was put on the sheet of the standard of the $5^{\text {th }}$ Zaslaw Uhlan Regiment: W PIERWSZA ROCZNICE BITWY POD KANIOWEM 11 MAJA 1919 ROKU OD KOŁA OPIEKI (On the First Anniversary of the Battle of Kaniów $11^{\text {th }}$ May 1919 From the Care Association). ${ }^{61}$ The military standard of the $7^{\text {th }}$ Lublin Uhlan Regiment from Mińsk Mazowiecki on the left-hand side under the image of Jesus Christ had the words: DAR ZIEMI LUBELSKIEJ (a Gift from the Lublin Region). ${ }^{62}$ The inscription with the content: MATKI, ŻONY, SIOSTRY (Mothers, Wives, Sisters) that was placed on the ribbon fastened to the flagpole of the standard of the $8^{\text {th }}$ Uhlan Regiment informed people about its funders. Similarly, on the ribbons of the standard of the $18^{\text {th }}$ Uhlan Regiment there was the dedication POMORZE SWOIM SYNOM (From Pomerania To Its Sons). ${ }^{63}$

Most flags and standards belonging to the units formed in 1919 in Greater Poland had this kind of inscription. The inscriptions, usually engraved in the metal ferrule of the flagpole, served to commemorate the collective or individual funders of those items. For example, there is the dedication on the flag of the $2^{\text {nd }}$ Greater Poland Riflemen Regiment: ZIEMIA WIELKOPOLSKA SWOIM SYNOM (from the Land of Greater Poland To Its Sons), or that on the flag of the $7^{\text {th }}$ Greater Poland Riflemen Regiment: ZIEMIA CHODZIESKA SWOIM OBROŃCOM I OSWOBODZICIELOM (from the Land of Chodzież To Its Defenders and Liberators), as well as the inscription on another vexillum:

\footnotetext{
${ }^{58}$ Kazimierz SATORA, Opowieści wrześniowych sztandarów [Tales of the September Standards] (Warszawa: Instytut Wydawniczy Pax, 1990), 165-165 and Fig. 170.

${ }^{59}$ Ibid., 205-206 and Fig. 192 with the wrong caption saying that it is the standard of the $11^{\text {th }}$ Infantry Regiment.

${ }^{60}$ GEPNER, "Sztandary," 249.

${ }^{61}$ Ibid., 249; SATORA, Opowieści wrześniowych sztandarów, Fig. 187.

${ }^{62}$ SATORA, Opowieści wrześniowych sztandarów, 197 and Fig. 190.

${ }^{63}$ GEPNER, "Sztandary," 248, 252.
} 
6-TEMU PUŁKOWI STRZELCÓW WIELKOPOLSKICH POWSTAŁEMU NA FRONCIE POD LESZNEM EDWARDOSTWO POTWOROWSCY Z GOLI (To the $6^{\text {th }}$ Greater Poland Riflemen Regiment Formed On the Front at Leszno, Mr and Mrs Edward Potworowski From Gola). ${ }^{64}$

On the regulation flags and standards of the Polish Army in the period of the Second Polish Republic the possibility was allowed of specifying the link between the unit and a certain place or region. This was done by placing the heraldic coat of arms and iconographic images in the shields between the arms of the cross on the left side of the sheet. On the other hand, persons and societies who rendered services towards the funding of the standards or officially participated in granting them were commemorated by inscriptions engraved on the heads of the nails fastening the sheets to the flagpoles. The nails were solemnly hammered in during the ceremony of the blessing of the standard and giving it to the military unit. The regulations of 1937 defined their number as 16 or 21 , depending on the size of the standard sheet. The first nail was hammered by the Military Ordinary of the Polish Army, the next ones by high state dignitaries and heads of the armed forces, starting with the President of the Republic of Poland, and also by representatives of the officers, non-commissioned officers and privates of the regiment. People representing local authorities and members of the funding committee also had to be present. ${ }^{65}$ The inscriptions engraved on the nail heads, most often having the form of decorative shields, made it possible to identify all of these people and circles. ${ }^{66}$

On the new military standards created in the period of World War II, inscriptions again appeared pointing to the funders of the items. On the standard of the Polish airmen in the West on the upper arm of the cross on the reverse side there is the inscription WILNO 1940 (Vilnius 1940). The inscription WILNO 1943 (Vilnius 1943) was put in an identical place on the abovementioned standard of the $1^{\text {st }}$ Bolesław Chrobry Armored Regiment formed by the Underground. Both of these military standards were made on the initiative of the Vilnius Poles, and were even produced by the same workshop be-

\footnotetext{
${ }^{64}$ Jarosław ŁUCZAK, "Choragwie i sztandary Wojsk Wielkopolskich [Flags and Standards of the Greater Poland Military]," Studia do Dziejów Dawnego Uzbrojenia i Ubioru Wojskowego 8 (1982): 114-122.

${ }^{65}$ KUKAWSKI, "Sztandary", 25

${ }^{66}$ As an example, Fig. 134 in K. Satora's work Opowieści wrześniowych sztandarów may serve; it shows the preserved nails from the standard of the $45^{\text {th }}$ Infantry Regiment of Równe with the inscriptions: "Ignacy Mościcki Prezydent Rzpitej” (!) (Ignacy Mościcki the President of the Polish Republic [with a spelling mistake]) and "Józef Piłsudski Marszałek Polski" (Józef Piłsudski, the Marshal of Poland).
} 
longing to nuns. ${ }^{67}$ The military standard of the Independent Parachute Brigade has the same contents pointing to the place and time the standard was funded. On its reverse side, on the upper arm of the cross over the image of St Michael the Archangel there is the name WARSZAWA (Warsaw) and the year 1942, as it was designed and made in the occupied capital, and then, like the abovementioned airmen's standard, sent secretly to Great Britain. ${ }^{68}$

Very often dedication inscriptions are found on vexilla belonging to units of the Polish People's Army. Phrases like: DAR POWIATU RADZYŃSKIEGO (a Gift from the Radzyń District) ( $7^{\text {th }}$ Łużyce Infantry Division), ŻOŁNIERZOWI POLSKIEMU MIESZKAŃCY BIAŁEGOSTOKU (from the Inhabitants of the Town of Białystok To the Polish Soldier) (the $9^{\text {th }}$ Drezdeńska Infantry Division), OBYWATELE XV DZIELNICY [Warszawa-Praga] 10 PUŁKOWI PIECHOTY (10 P.P.) (the Citizens of the $15^{\text {th }}$ Quarter [Warsaw-Praga] To the $10^{\text {th }}$ Infantry Regiment), DAR OB[ywateli] GM[iny] PAWŁów. P[owiat] CHEŁM (a Gift from the Citizens of the Pawłów Common. The Chełm District) (the $14^{\text {th }}$ Sudecka Anti-Tank Artillery Brigade), MIASTO CHEŁM 24 PUŁKOWI ARTYLERII SAMOCHODOWEJ (the Town of Chelm To the $24^{\text {th }}$ Self-Propelled Artillery Regiment). ${ }^{69}$ The frequent placing of this kind of inscription on the flags of formations subjected to Communist authorities was surely not accidental. It was probably to be proof of acceptance of the new order by the Polish society and was to point to the close relations between the army and the inhabitants of the places where the units were formed.

On the vexilla designed for underground and guerilla formations the inscriptions referring to the funders for obvious reasons do not appear too often. This is why the inscription on the flag of the Self-Defence Center in Przebraże in the Volhynia Area of the Home Army should be considered rather special; its wording is as follows: PRZEBRAŻE OD KOMENDANTA S[amo]O[brony] MALINOWSKIEGO L[udwika] NA CZEŚĆ ZWYCIĘSTWA NAD BANDEROWCAMI 30-VIII 1943 R (Przebraże From the Commander of the Self-Defence Unit Malinowski Ludwik In Honor of the Victory Over the Banderites 30-VIII 1943). ${ }^{70}$ In addition, a rarely seen case happens here when the dedication mentions one man only, probably the originator of the making of the flag that was produced by local women.

The third group of inscriptions may be called commemorative, as they re-

\footnotetext{
${ }^{67}$ NeY-KrwawiCZ, Sztandary i proporce, 54.

${ }^{68}$ Murgrabia, Symbole wojskowe, 37-39.

${ }^{69}$ BigoszewSKa and Wiewióra, Sztandary Ludowego Wojska Polskiego, 59-60, 67-68, 81$82,119-120,125-126$.

${ }^{70}$ NeY-Krwawicz, SiemaszKo, and SiemaszKo, Bojowe sztandary i proporce, 96-99.
} 
fer to important events connected with the history and tradition of the unit to which the vexillum belonged. Usually they were names of places and dates pointing to the place and time of such events. It is well understood that on such military units standards, battles in which the units took part were first of all commemorated. Sometimes war episodes were also mentioned with the participation of the earlier existing formations, to which the units owning the flags referred in their tradition. However, the places where the units were formed, or even contents connected with e.g. their patrons could also be commemorated in this way. The inscriptions were placed on flags and standards either when they were made, or later, often with the addition of new elements that demonstrated the military successes of the owners of the objects.

In the Polish Army Museum the trucks of flags from the time of the Kościuszko Uprising are preserved; they are supplied with metal plaques with inscriptions informing us about the use of these vexilla by the Insurrection troops. The content of one of them is the following: POWSTANIE NARODU DN. 24-TE MAR. POD TADEUSZEM KOŚCIUSZKI (Insurrection of the Nation On $24^{\text {th }}$ March Under Tadeusz Kościuszko); there is also another inscription that is nearly identical. ${ }^{71}$

Placing this kind of information on regulation flags in the interwar period was standardized by the legislation of that time. It allowed its presence in the form of images or inscriptions on the left-hand side of the sheet. ${ }^{72}$ It was then that inscriptions with information about places and dates important for

\footnotetext{
${ }^{71}$ Muzeum Wojska Polskiego w Warszawie. Katalog zbiorów. Wiek XVIII, 156-157 (Items 347-348).

${ }^{72}$ The Act of $1^{\text {st }}$ August 1919 included the statement: "On one side of a regiment standard substitution is allowed of the proper coat of arms with special emblems and inscriptions that have to be approved by the Chief of State on a proposal from the Council of Ministers." Journal of Laws of the Republic of Poland, No. 69 of $28^{\text {th }}$ August 1919, par. 416, p. 6. In practice this consisted of substituting the number of the regiment on the left-hand side of the sheet with coats of arms and images of saints placed in small shields between the arms of the cross and in adding inscriptions on its arms. Such a possibility was more precisely indicated by successive acts. The President's Order of $13^{\text {th }}$ December 1927 contained the regulation: "The wreaths in the corners and the figures of the Regiment on the left-hand side of the standard may be substituted by other emblems placed on shields, whose models will be approved by the President of the Republic of Poland on a proposal of the Minister of Military Affairs." Journal of Laws of the Republic of Poland, No. 115 of $28^{\text {th }}$ December 1927, par. 980, art. 7. Next, the President's Decree of $24^{\text {th }}$ November 1937, with reference to the appearance of the left side of the standard sheet, decided: "Between the arms of the cross, in the corners of the sheet ... in the wreaths or on the shields, numbers or emblems of the formation, the initials of the commander of the formation, images of saints, coats of arms or emblems of the places connected with the history of the formation etc. may be placed. On the arms of the Knight's Cross names of places and dates connected with the history of the formation may be placed." Journal of Laws of the Republic of Poland, No. 5 of $28^{\text {th }}$ January 1938, Art. 10).
} 
the units started covering their military standards. Among many such objects it is worth paying attention to at least some examples. In 1921 the $2^{\text {nd }}$ Kaniowski Sapper Regiment received a regulation standard that in the corners of the reverse side of the sheet, between the arms of the cross, had inscriptions on the shields: KANIÓW 11.5.18, SZAMPANIA 19.7.18, LWÓW 12.2.19 (Kaniów, Champagne, Lvov) and WARSZAWA 18.8.20 (Warsaw). ${ }^{73}$ They reflect the combat traditions of this unit, including both its actions as part of the II Corps in Russia and of Gen. Haller's "Blue Army" in France, as well as its participation in battles against Ukrainians and Bolsheviks on Polish territories.

Episodes of the Polish-Soviet War, in which the $42^{\text {nd }}$ Infantry Regiment from Białystok took part, were noted on the flag given to it in 1921 in the form of an inscription on the arms of the cross on the left-hand side of the sheet: STRUGA 18-III-1920; KRZEMIENIEC 12-VII-1920; MLAWA 21-VIII-1920 and DUBIENKA $11-\mathrm{IX}-1920 .{ }^{74}$ Then, on the standard of the $5^{\text {th }}$ Heavy Artillery Regiment from Krakow, two places are commemorated: KRAKÓW $31 \bullet X \cdot 1918$ and DYNEBURG (Daugavpils) $3 \cdot 1 \cdot 1920 .{ }^{75}$ In this case, the first part of the inscription probably refers to the date of the formation of the unit, and the second to its participation in the battles on the Daugava, where, as part of operation "Winter", Polish troops supported Latvians fighting against the Bolsheviks. The inscriptions in the shields between the arms of the cross on the left-hand side of the sheet of the standard of the $19^{\text {th }}$ Uhlan Regiment gave information about the history of the units from which the regiment was derived: DYWIZJON JAZDY KRESOWEJ 1918-1919 (Kresowa Cavalry Division), IV WOŁYŃSKI DYWIZJON I PUŁK (IV Volhynia Division I Regiment) 19191920, JAZDA OCHOTNICZA M[a]J[o]RA JAWORSKIEGO [Major Jaworski's Voluntary Cavalry] 1920 R., PUŁK UŁANÓW WOŁYŃSKICH (Volhynia Uhlan Regiment) $1920 .{ }^{76}$ World War II brought new contents to the standards of Polish formations reflecting their rich combat route on all fronts. On the reverse side of the sheet of the aforementioned standard of the Independent Parachute Brigade, on the arm of the cross there is the inscription: ARNHEMDRIEL $18-26 \bullet I X \cdot 1944$. It is obvious that it was placed there only after the bat-

\footnotetext{
${ }^{73}$ SATORA, Opowieści wrześniowych sztandarów, 348-349 and Fig. 263. The $2^{\text {nd }}$ Sapper Regiment was formed in 1921 on the basis of the $2^{\text {nd }}$ Engineering Regiment of the II Corps in Russia, and in the years 1929-1939 became the $2^{\text {nd }}$ Sapper Battalion which was restored as a regiment before the September Campaign (the Invasion of Poland).

${ }^{74}$ Ibid., 91 and Fig. 130 (with the wrong caption saying that the figure shows the standard of the $43^{\text {rd }}$ Infantry Regiment from Białystok).

${ }^{75}$ Ibid., 329-330 and Fig. 239.

${ }^{76}$ GEPNER, "Sztandary," 252.
} 
the the Brigade fought near those towns. The standard of the $5^{\text {th }}$ Kresowa Infantry Division, given to this formation in Palestine in 1943, on the main side between the arms of the cross has the names of towns in laurel wreaths: LWÓw (Lvov), WILNO (Vilnius), TOCK (Totsk), TATISZCZEW (Tatishchevo). The first two were the two most significant cities in the Kresy (the Eastern Borderlands), and the last two the centers where the Polish Army in the USSR was formed. The Carpathian Uhlan Regiment that was also part of the II Corps, received its standard after the end of the combat actions, in November 1945 in Rome, and it had on the main side of the standard, on the arms of the cross, the names of the towns for which it fought: TOBRUK, MONTE CASSINO, ANCONA, BOLOGNA. ${ }^{77}$

The sheets of the standards that were owned by units of the Polish People's Army that, starting from 1943, fought at the side of the Red Army, were also frequently covered with inscriptions commemorating the tradition of those formations. On the main side of the military standard of the $5^{\text {th }}$ Pomerania Heavy Artillery Brigade in the corners of the sheet the names of four towns along with the dates of the events that were connected with the history of that unit were placed: SMOLEŃSK 12.X.43; WAKINO (Vakino) 21.X.43; DOLSK 12.VI.44 and PRAGA (Prague) 14.IX.1944. Similarly, the sheet of the standard of the $1^{\text {st }}$ Warsaw Engineering-Sapper Brigade was supplied with the inscriptions: OSTRÓW 15.VI.44; PUŁAWY 2.VIII.44; WIELKOLAS 15.VIII.44; SASKA KĘPA 14.IX.44 and WARSZAWA 16.I.45. This last inscription was obviously added after the standard was handed to the unit, which happened in December $1944 .^{78}$

Another group of inscriptions on the standards of the LWP (Ludowe Wojsko Polskie - Polish People's Army) contained the same dates of events connected with the patrons of the units. For example, on the standard of the $2^{\text {nd }}$ J.H. Dąbrowski Infantry Division, in one of the wreaths placed in the corners of the sheet between the arms of the cross, there is the date of the oath ceremony that was performed in the Division: 1943.11.XI, and in the other 1797 is placed, that is, the year when the Legions were formed in Italy by the patron of the Division. ${ }^{79}$ In the same way, on the military standard of the $3^{\text {rd }} \mathrm{R}$. Traugutt Infantry Division there are the dates 1944.26.III and 1863 (the January Uprising), the standard of the $4^{\text {th }} \mathrm{J}$. Kiliński Infantry Division had 1944 and 1794 (the Kościuszko Uprising), that of the $1^{\text {st }}$ E. Plater Independent Women's Battalion 1943 15.VII. and 1831 (the November Uprising)

\footnotetext{
${ }^{77}$ MuRgRABIA, Symbole wojskowe, 39-47.

${ }^{78}$ BigosZewSKA and Wiewióra, Sztandary Ludowego Wojska Polskiego, 116-117, 144.

${ }^{79}$ Ibid., $18-20$, on p. 20 the first of the dates was wrongly interpreted as 1943.11.IX.
} 
and that of the $1^{\text {st }}$ J. Bem Warsaw Heavy Artillery Brigade - 1943 11.XI and 1848 (the Revolution of 1848). Similarly, the units of the LWP whose names referred to the September Campaign had dates connected with it on their standards. The $1^{\text {st }}$ Armored Brigade of the Defenders of Westerplatte: 1939 1-8.IX and the $1^{\text {st }}$ "Warszawa" Fighter Aviation Regiment: 1939 1-27.IX. ${ }^{80}$

On the vexilla that underground and guerilla units had in the period of the last war inscriptions may also be seen commemorating particular activities. The standard of the Kolno Sub-district in the Białystok area was supplied with the date of 13 IX 1939 signifying the beginning of the conspiracy in that town. In turn, the standard of the "Grunwald" Platoon that was part of the $11^{\text {th }}$ Uhlan Regiment from Lvov, formed for several years during the German occupation and after the Soviets' second entry into Lvov, initially had on its main side on the lower side of the cross the dates of the unit's existence: 1940-194. In the latter of these dates the last figure was not added since it was not known when the war would end. During the last assembly of the platoon in Lvov in 1946 it was decided that it was that year that should be put on the standard and the figure 6 was added. However, the threat constituted by the Communist authorities, for whom the year 1946 placed on the standard was proof of the hostile activities of the former soldiers of the platoon, made the people taking care of the standard change the date from 1946 to 1944 and this version has remained on it till now. ${ }^{81}$ One special way of commemorating the services rendered during the war by particular units was decorating them with the Virtuti Militari Order. Usually it was reflected in fastening the bars of the order with a ribbon bow in the colors of the order to the standard. In a case when the decorated unit deserved the order once again, the ribbon might be fastened to its standard with an inscription of the type: WYRÓŻNIONY ZA NIEZWYKŁE MĘSTWO W KAMPANII 1939 ROKU W POLSCE (6 P. P. Leg., 35 P. P., 14 P. Uł. Jazłowieckich) (Awarded For Exceptional Valor In the 1939 Campaign In Poland $-6^{\text {th }}$ Legion Infantry Regiment, $35^{\text {th }}$ Infantry Regiment, 14 Jazlowiec Uhlan Regiment), or: WYRÓŻNIONY ZA NIEZWYKŁE MĘSTWO ZA KAMPANIĘ WE WŁOSZECH 1944-1945 ROKU (1 P. Uł. Krechowieckich) (Awarded For Exceptional Valor In the 1944-1945 Campaign In Italy (the $1^{\text {st }}$ Krechowce Uhlan Regiment). ${ }^{82}$

The last of the groups of inscriptions seen on vexilla may be called mottos. They comprise all the texts that have the character of watchwords, slogans, sentences, mottos, apostrophes or invocations, commonly occurring

\footnotetext{
${ }^{80}$ Ibid., 37-44, 102-107, 137-140, 153-136.

${ }^{81}$ NeY-KrwawiCZ, Sztandary i ptoporce, 44, 48.

${ }^{82}$ KUKAwSKI, “Sztandary,” 34; SATORA, Opowieści wrześniowych sztandarów, Fig. 184.
} 
over centuries on the items discussed here. ${ }^{83}$ They usually had the form of lofty, solemn formulas with a religious, moral and patriotic character. In Poland they probably appeared in the $16^{\text {th }}$ century. On the flags belonging to the rebellious Gdańsk inhabitants that were captured by Stefan Batory's army at Lubieszew, there were inscriptions in German: "Golden freedom", "Freedom more precious than gold ${ }^{84 "}$. It may be supposed that at that time the custom of putting inscriptions of this type on military standards appeared among in Polish troops as well. In a description of Jan Zamoyski's wedding to Gryzelda Batorówna that took place in 1583 there is information that on the flags carried by the Hetman's troops that honored the ceremony, beside the coat of arms of Jelita there were the mottos: CERNIT ET AUDET and UTRAQUE CIVIS. ${ }^{85}$ Maybe such inscriptions were more often put on military standards of the units under the command of this dignitary, because the mottos quoted have also been preserved on other objects connected with him.

Numerous vexilla supplied with this kind of inscriptions dating from the $17^{\text {th }}$ century are known. One of Polish flags kept in the Royal Armory in Stockholm, probably captured by the Swedes before 1629, on one side of its sheet, under the image of the Mother of God with Child, has the Latin words PROVOCATUS PUGNUM, and on the other side the image of Christ on the cross surrounded by the sun and the moon and the inscription DEUS ADIUTOR MEUS. ${ }^{86}$ On a flag belonging to Sigismund III Vasa's court troops dating back to the same period, over the Eagle placed against the background of a white cross and surrounded with the chain of the Golden Fleece there was the motto: TECVM ET PRO TE. ${ }^{87}$ In turn, on the sheet of the flag handed by the Papal Nuncio to Prince Władysław Vasa before he went to Chocim in 1621 there was the Eagle with a cross and the inscription: PRO GLORIA CRUCIS. ${ }^{88}$ The motto PRO DEO REGE ET PATRIA accompanied the image of St Michael

\footnotetext{
${ }^{83}$ For the meaning of these names see Stownik terminów literackich [A Dictionary of Literary Terms], ed. Janusz Sławiński (Wrocław: Ossolineum, 2002), 40 ('apostrofa' [apostrophe]), 191 ('hasło' [watchword]), 221 ('inwokacja' [invocation]), 512 ('slogan' [slogan]).

84 "Kronika z czasów króla Stefana Batorego 1575-1582 [A Chronicle of King Stephen Báthory's Times 1575-1582]," ed. and supplied with introduction by Henryk Barycz, Archiwum Komisji Historycznej, series 2, vol. 3 (vol. 15 of the whole collection): 375: "nostri coeperunt [...] vexilla, in quibus auro Germanica verba erant descripta: Libertas preciosor auro, Aurea libertas".

${ }^{85}$ Bartosz PAProcki, Herby rycerstwa polskiego [Polish Knights' Coats of Arms], ed. Józef Kazimierz Turowski (Kraków: Biblioteka Polska, 1858), 881.

${ }^{86}$ Michał LisıŃski, "Polonica w Szwecji [Polish Materials in Sweden]," Wiadomości (London) 1967, No. 5, the text on the Internet website: http://www.zwoje-scrolls.com/zwoje/index.html.

${ }^{87}$ BRZEZIŃski, Polish Armies 1569-1696, 46 and Fig. H.

${ }^{88}$ Władysław CZAPLiński, Władysław IV i jego czasy [Władysław IV Vasa and His Times] (Warszawa: Wiedza Powszechna, 1972), 61.
} 
the Archangel on the flag of the levy in mass of the Witebsk Voivodeship of $1654 .{ }^{89}$ The same figure present on the military standard belonging to the Starodub Sword-bearer Jan Sławiński's Cossack unit is supplied with a pennant with the inscription KTO JEST JAKO B[ó]G (who is like God). ${ }^{90}$ On other Polish vexilla captured by the Swedes in the $17^{\text {th }}$ century are also mottos with religious contents, among others: IN HOC SIGNO VINCES or IESVS MARIA IOZEF. ${ }^{91}$ The flag of the Krakow Bishop P. Gembicki's infantry from the time of the "Swedish Flood" on its left side had the image of the Mother of God and the inscription: SVB TVVM PRAESIDIUM CONFVGIMVS. ${ }^{92}$ As may be assumed on the basis of the examples cited, the inscriptions on military flags from the times of the Vasas usually had a lofty and solemn significance referring to religious and patriotic values. On the flags captured by the Swedes in the fights against the Republic of Poland's army there are sentences with a more universal significance, such as FORTVNA FALLIT SPES ALIT PATIERNTIA VINCIT CONSTANTIA SOLA TRIVMPHAT (with the Mitawy coat of arms on its sheet, used in 1626) or TANDEM BONA CAVSA TRIVMPHAT (the property of Sigismundus III Vasa's Infantry Guard). ${ }^{93}$

In some cases the content of the inscriptions could reflect current problems and events; an example of this is the motto on the flag used by John II Casimir Vasa during his stay abroad in the period of the "Swedish Flood", which is now kept in the Army Museum in Stockholm. It reads CAELITUS ERIGOR [with the help of Heaven I am rising], which is a reference to the difficult situation in which the monarch found himself. The image on the same vexillum has a similar meaning; it shows the Wheat Sheaf, the Vasas' coat of arms, surrounded on both sides by black clouds from which gusts of wind and streams of rain fall on it; however, a hand supporting it also appears. Hence, the whole forms a composition typical of emblematic art. ${ }^{94}$

\footnotetext{
${ }^{89}$ Muzeum Wojska Polskiego w Warszawie. Katalog zbiorów. Wiek XVII, 194.

${ }^{90}$ Ibid. In the description of this object there is an interpretation of the illegible inscription that is partly wrong - it says that it is the formula KTO JEST JAKO D[ei] G[ratia] (who is like D[ei] G[ratia]. In this case, it was rather the motto that is an explanation of St Michael the Archangel's name: Michael $=$ Who is like God.

${ }^{91}$ Pictures of these flags are found in Aleksander Brückner's Encyklopedia staropolska, vol. 3 (Warszawa: Nakładem Księgarni Trzaski, Everta i Michalskiego, 1939), col. 615-616.

${ }^{92}$ GrabowSKI, "Polskie choragwie z XVI-XVIII wieku," 15 (where the inscription is incorrectly interpreted) and Table $\mathrm{V}$.

${ }^{93}$ Ibid., 13.

${ }^{94}$ The same content is found on John II Casimir's medals struck at that time, that played a great propaganda role in the war fought against Sweden. Cf. Maria Stahr, Medale Wazów w Polsce 1587-1668 [The Vasas' Medals in Poland 1587-1668] (Wrocław: Ossolineum, 1990), 172.
} 
A similar example of baroque production may be seen on the reverse side of this vexillum, where a hand with a sword appearing from clouds and the motto PRO REGE ET PATRIA are placed. ${ }^{95}$ It is obvious that the contents of many vexilla dating from that period were inspired by the rules according to which stemmata and emblems were created, where a coat of arms or an image were accompanied by a short line called a motto, a lemma, an epigraph or an inscription. ${ }^{96}$

In the $18^{\text {th }}$ century on the flags used in the Republic of Poland slogans were present that still had a lofty ideological meaning. Flags with the coats of arms of Courland that was a Polish fiefdom, captured by the Swedes at the times of Augustus II the Strong and still kept in Stockholm, have the inscriptions VIGILANTER ET CONSTANTER [Vigilantly and Constantly] and PRO DEO REGE ET PATRIA. ${ }^{97}$ Another flag belonging to that monarch that also was captured by the Swedes during the Northern Wars has on its sheet the image of the so called Cross of Burgundy along with the inscription PRO FIDE REGE ET PATRIA. ${ }^{98}$ Hence we are dealing here with a similarity, surely not accidental, to the motto of the Order of the White Eagle instituted by that monarch in 1705 that read "Pro Fide Lege et Rege". Its modified version was placed on the Confederation flag dating from the times of the struggles between the supporters of Augustus II and those of Stanisław Leszczyński, whose flag at present is kept in Wawel Castle. On its sheet it has the image of the White Eagle and the inscription PRO FIDE LEGE ET AUGUSTO REGE, with traces of the substitution of the word "Stanislao" with the word "Augusto". This proves that the flag was seized by the supporters of the Vettin from the hands of Leszczyński's backers. ${ }^{99}$ This could, at the same time, point to the fact that the Saxon's opponents used the motto of the order that he had instituted.

The author quotes a slightly changed version of the motto, that is: COELITUS ERIGOR, but the picture of the medal on p. 171 clearly shows that it was identical with the one on the discussed flag.

${ }^{95}$ STAHR, Medale Wazów w Polsce, 172, footnote 34; colored images of both sides of this relic are shown in the publication: Polska. Dzieje cywilizacji i narodu [Poland, History of the Civilization and the Nation], vol. 4: Rzeczpospolita szlachecka 1586-1795 [The Noblemen's Republic 1586-1795], ed. Marek Derwich (Warszawa, Wrocław: Ossolineum, 2003), 85

${ }^{96}$ The third part of the emblem was a rhyming piece called a subscription, see Janusz PeLC, Barok - epoka przeciwieństw [Baroque - an Epoch of Contrasts] (Warszawa: Czytelnik, 1993), $180-182$.

${ }^{97}$ GraBOWSKI, "Polskie choragwie z XVI-XVIII wieku," 24.

${ }^{98}$ Ibid., 8 and Table VIII.

${ }^{99}$ Orzel Bialy - 700 lat herbu Państwa Polskiego [The White Eagle - 700 Years of the Emblem of the Polish State] (Warszawa: Zamek Królewski, 1995), Catalogue, item III.36. 
During the reign of Augustus II mottos with a different content were also placed on the military vexilla, which is proven by the image of one of the Infantry flags on Mock's famous painting showing the so-called "kampament" (display) of Polish and Saxon troops in the vicinity of Warsaw in 1732. On the edge of its crimson sheet the inscription DEO FIDEM REGI FIDELITATEM LEGI OBSEQVUIM can be seen. ${ }^{100}$ However, the motto of the Order of the White Eagle probably soon stopped being associated with the Vettins, or even with the very king's power. Flags that were owned by members of the confederations formed in the $18^{\text {th }}$ century may indicate this. The flag of the "serious formation" subordinate to the Starost of Gostyn from the times of the Dzików Confederation had a cross on the sheet, and under it the inscription: PRO FIDE : PATRIA : LEGE ET REGE. ${ }^{101}$ As may be seen, the above mentioned motto was expanded by addition of the word "Patria". And its typical version, PRO FIDE REGE ET LEGE, is placed on the arms of the Knight's Cross on the sheet of the flag probably belonging to the Bar confederates. On the other hand, another flag, one used by the members of this movement in the years 1770-1772, has the inscription PRO FIDE LEGE ET PA[tria]. The last word of the motto - "king" - was then substituted by "homeland", which could have resulted from the dethronement of Stanisław August Poniatowski proclaimed by the Generalność ("Generality", that is, the leadership) of the Confederation on $13^{\text {th }}$ October $1770 .^{102}$

Military standards (the so called cornets) of the $18^{\text {th }}$ century dragoon formations had lofty mottos. A cornet dating from the time of Stanisław Leszczyński may serve as an example here; it had the White Eagle flying towards the sun, and above it there was a ribbon with an inscription in black: TURBINE DISCUSSO PAR SUMMIS FERRE SERENUM [After the Tempest Is Hushed Up It Is Possible To Bring Good Weather To the Highest Ones]. ${ }^{103}$ The same coat of arms, in the form of an eagle flying towards the sun, was also placed on dragoon cornets in 1764, but was accompanied by a different inscription: TENDIT IN ARDUA VIRTUS [Valor Aspires to Difficult Things]. On the lefthand side of the sheet a further changed version of the order's motto mentioned above appears: PRO FIDE LEGE ET LIBERTATE. ${ }^{104}$

\footnotetext{
${ }^{100}$ GemBARZEWSKI, Żolnierz polski, vol. 2, 118-119.

${ }^{101}$ Ibid., 42-43.

${ }^{102}$ Muzeum Wojska Polskiego w Warszawie. Katalog zbiorów. Wiek XVIII, 150 (item 331), 149 (item 328).

${ }^{103}$ Ibid., 145, item 315; Stanisław Gepner ("Sztandary," 242) dates the cornet to the times of Stanisław August and also translates the quoted inscription in a slightly different way: "Having hushed up tempests one should bring good weather to Heaven."

${ }^{104}$ Muzeum Wojska Polskiego w Warszawie. Katalog zbiorów. Wiek XVII, 148, item 323.
} 
A whole group of $18^{\text {th }}$ century military standards also has inscriptions with religious contents. One is the flag that belonged to Stanisław Denhof, the Field Hetman of the Grand Duchy of Lithuania, dating from 1718, has on the reverse side a painted image of the Virgin Mary of Immaculate Conception, and a golden inscription over it: SUB TUUM PRAESIDIUM COFUGIMUS. ${ }^{105}$

Religious symbolism commonly occurred on the standards belonging to the Bar confederates. A flag in the collection of the Polish Army Museum in Warsaw was probably their property; on both sides of the crimson sheet it has the image of the White Eagle, and on its breast there is the figure of the Mother of God holding a burning heart in her crossed hands. On the right side of the sheet is placed the inscription: SUB TUUM PRAESIDIUM CONFUGIMUS, and on the left: SUB UMBRA ALARUM TUARUM PROTEGE NOS. PS. XCI. [In the Shade of Your Wings Shield Us. Psalm 91]. Another flag that is linked with that confederation also has, beside the image of the Mother of God against the background of the cross and the above mentioned motto: PRO FIDE REGE ET LEGE, the invocation: MONSTRA TE ESSE MATREM on the right-hand side, and on the reverse, along with the image of St Joseph in the middle of the cross, there is the inscription missing the initial part: ...IOSEPH ORA PRO NOBIS. ${ }^{106}$

The Kościuszko Uprising in 1794 brought new mottos that also found their place on the military standards of the formations fighting under the Commander-in-Chief's orders. The best known vexillum dating from that period is the flag of the Krakow Grenadier Battalion (scythe-bearer battalion) handed to the representative of the formation by Kościuszko on $16^{\text {th }} \mathrm{Ju}$ ly 1794. On its crimson silk sheet there is a wheat sheaf surrounded with a laurel wreath, over it a "magierka" cap, at the back a pike and a scythe crossed, and at the top the inscription embroidered with white silk: ŻYWIA Y BRONIA (they feed and they defend). On other flags dating from that period that have been preserved, albeit with damaged sheets, the words WOLNOŚĆ CAŁOŚĆ... (Freedom, integrity) are preserved. They are doubtless part of the motto accepted by the leaders of the uprising: "Freedom, integrity, independence". ${ }^{107}$ A flag was also used with the inscription: NIECH ŻYJE POLSKA (Long live Poland), accompanying the image of the White Eagle. ${ }^{108}$

\footnotetext{
${ }^{105}$ GemBARZeWSKI, Żotnierz polski, vol. 2, 120-123

${ }^{106}$ Muzeum Wojska Polskiego w Warszawie. Katalog zbiorów. Wiek XVIII, 150 (item 329), 151 (item 151)

${ }^{107}$ Ibid., 156-157 (items 346-348).

${ }^{108}$ KUCZYŃSKI, RUSSOCKI, and WiLlaume, Godło, barwy i hymn Rzeczypospolitej, 138.
} 
A variety of mottos may be found on the sheets of the vexilla used by Polish troops formed at the side of France after the fall of the Republic of Poland. On the abovementioned flag of the $1^{\text {st }}$ Fusilier Battalion that was formed in 1797 in Lombardy on the main side there are inscriptions in Italian, and among them the motto TUTTI GLI UOMINI LIBER / SONO FRATELLI, and on the reverse side the same content but in Polish: WSZYSCI LUDZIE WOLNI SA BRACIA (All Free People Are Brothers). ${ }^{109}$ The flag of the FrenchPolish Guard Regiment of 1807 on the left side of the sheet had the inscription MIŁOŚĆ OYCZYZNY (Love of the Homeland). ${ }^{110}$ The inscription on the pennant of a rather modest size that belonged to a colonel of the $1^{\text {st }}$ Polish Light Cavalry Regiment of the Imperial Guard is unusually developed. On its main side along the flagpole are placed the words: ZNAMIE POLAKA (A Pole's Badge), and in the rays of the six-pointed star with the White Eagle in the middle there are the inscriptions: CNOTA, PRAWO, RZĄD, OYCZYZNA, HONOR, WŁASNOŚĆ (Virtue, Law, Government, Homeland, Honor, Property). Between the arms six groups of words were additionally placed, three in each: CZUŁOŚĆ, SPRAWIEDLIWOŚĆ, LUDZKOŚĆ; OŚWIECENIE, PRACA, SKROMNOŚĆ; POSŁUSZEŃSTWO, GORLIWOŚĆ, WIERNOŚĆ; POŚWIĘCENIE, POJEDNANIE, STAŁOŚĆ; ODWAGA, MĘSTWO, KARNOŚĆ; SKROMNOŚĆ, OSZCZĘDNOŚĆ, PRZEZORNOŚĆ (Tenderness, Justice, Humanity; Enlightenment, Work, Modesty; Obedience, Zealousness, Fidelity; Sacrifice, Reconciliation, Constancy; Courage, Valor, Discipline; Modesty, Frugality, Caution). On the reverse side of this sheet, apart from other inscriptions, were placed the words: ZNAK ZWYCIĘSTWA (Sign of Victory). In the army of the Duchy of Warsaw vexilla were also seen that carried lofty mottos on their sheets. One of the two flags of the $4^{\text {th }}$ Regiment may serve as an example here, where over the image of the crowned Eagle there was the inscription: GDY SIE CHCE BRONIĆ NIE INNYCH CIEMIĘŻYĆ HASŁO POLAKA ZGINĄĆ LUB ZWYCIĘŻYĆ (When One Wants to Defend Others And Not to Oppress Them, a Pole's Motto Is to Die Or to Win). ${ }^{111}$

In the army of the Kingdom of Poland on the regulation standards and flags no mottos or other slogans were placed and it was in this form that they were to be used - after removing the monograms of the Tsar's name - by particular units during the November Uprising. On the other hand, the vexilla made for new formations during the Uprising, marked by a lot of freedom

\footnotetext{
${ }^{109}$ GemBarZEWSKI, Żotnierz polski, vol. 3, Table 4.

${ }^{110}$ Ibid., Table 78.

${ }^{111}$ Ibid., Tables 80 and 159.
} 
as far as their appearance was concerned, were frequently supplied with inscriptions that had the form of slogans. One was the flag of the Krakow and Sandomierz Marksman Regiment having the embroidered inscription on its reverse side: TYM KTÓRZY W BOJU UPRAGNĘLI SŁYNĄĆ DWIE TYLKO DROGI ZWYCIĘŻYĆ LUB ZGINAĆ (Those Who Desire to Be Famous In Battle Have Two Ways Only, to Win Or to Die). ${ }^{112}$ This lofty slogan that had to reflect the fighting soldiers' determination, is fairly similar to the slogan quoted above from the flag used at the times of the Duchy of Warsaw. On the reverse side of another insurgent flag, used in the Battle of Olszynka Grochowska, there was the inscription: WOLNOŚĆ NIEPODLEGŁOŚĆ ROK 1830 (Freedom Independence 1830).

A special role was to be played by several dozen flags that were made of white linen and on which the motif of the cross was placed along with a motto written on one side in Polish: W JMIE BOGA ZA NASZA I WASZĄ WOLNOŚĆ (In the Name of God For Our Freedom And Yours), and on the other in Russian: VO IMIA BOGA ZA NAŠU I VAŠU VOL'NOST'. The intention was to make soldiers not only in the Polish ranks but also in the Russian army realize that the insurgent struggle was a struggle for liberation. This is why they were hoisted in such places where they were likely to be captured by Russians. ${ }^{113}$ In the past those flags were associated with the January Uprising, but detailed research showed that they had been made in 1831 on the initiative of members of the Patriotic Society. Probably J. Lelewel or A. Gurowski was the author of the motto placed on them. ${ }^{114}$

After the failure of the November Uprising the Poles' aspirations for freedom still found reflection in the mottos placed on the sheets of flags and standards used during action of various types. In the Austrian Captain Peck's memoirs describing the stay of Polish troops interned in Zator in the autumn of 1831 , information may be found about a celebration organized on $4^{\text {th }}$ November in the local church, during which, on the catafalque, a white-red-blue flag was placed that had the Polish-Lithuanian coat of arms on one side, and on the other the inscription: SZCZĘŚLIWY NARÓD, KTÓRY SAM UMIE RZĄDZIĆ SIĘ-PRECZ Z WSZELKIMI MONARCHAMI, BĘDACCYMI TYLKO TYRANAMI LUDÓw! (Happy is the Nation That Can Rule Itself-Down With All Mon-

\footnotetext{
112 Ibid., vol. 4, Table 135.

${ }^{113}$ KUCZYŃSKI, Russocki, and WiLlaume, Godło, barwy i hymn Rzeczypospolitej, 169.

${ }^{114}$ Wanda BigoszewSKA, "Proporzec z 1831 r. świadectwem genezy hasła 'Za naszą i waszą wolność" [The 1831 Pennant As a Testimony of the Origin of the Motto "For Our Freedom and Yours," in Muzealnictwo Wojskowe [Military Museology], vol. 4, ed. Muzeum Wojska Polskiego [Polish Army Museum] (Warszawa: Wydawnictwo Ministerstwa Obrony Narodowej, 1989), 316-326.
} 
archs Who Are Only Tyrants of the People!). It is not known if it had been used as the military standard of some of the interned units or if it was only made for the celebration. However, the inscription with the radical content that was placed on it must have raised reservations from the Austrian authorities. They confiscated the flag, but later Poles stole it away. ${ }^{115}$

The contents placed on flags used by Poles during the Revolutions of 1848 reflected the ideas of revolution and liberation that motivated them at that time. For example, the military standard of the Polish Legion in Baden in 1849 on the red sheet had the inscription RÓWNOŚĆ, BRATERSTWO, DOBROBYT DLA WSZYSTKICH (Equality, Brotherhood, Prosperity For All). The legion commanded by Józef Wysocki that fought in Hungary, used the flag that was mentioned above, one that on its left side had the image of the Eagle and the motto: ZA WOLNOŚĆ NASZĄ I WASZĄ (For Our Freedom and Yours). ${ }^{116}$

Religious and patriotic symbolism was used in the contents of the inscriptions that were placed on flags and standards used during the January Uprising. This is proven by the preserved specimens of vexilla dating from those times. It is worth paying attention to the previously mentioned "riflemen and scythe-bearers" flag that belongs to the Polish Army Museum collection. On its main side there is the image of the Black Madonna of Częstochowa with the inscription POD TWOJĄ OBRONE UCIEKAMY SIĘ ŚWIĘTA BOŻA (Beneath Thy Protection We Take Refuge O Mother of God) in the lower frame, and over the picture are embroidered the words NAJŚWIĘTSZA MARJO PANNO (The Most Blessed Virgin Mary), and underneath BROŃ NAS OD POCISKÓW NIEPRZYJACIÓ£ (Defend Us From the Enemy's Bullets). The inscription on the reverse side of this flag may also be considered a kind of motto: BEZPARDONNI ZA WOLNOŚĆ RÓWNOŚĆ NIEPODLEGŁOŚĆ POLSKI (The Merciless for Freedom, Equality, Independence of Poland). ${ }^{117}$ On the insurgents' flag kept in the collection of the Historical Museum in Wrocław the image of the Black Madonna of Częstochowa placed in the center of the three-field coat of arms of Poland, Lithuania and Ruthenia is accompanied by the Latin inscription: REGINA REGNI POLONIAE ORA PRO NOBIS. ${ }^{118}$ Other military stand-

\footnotetext{
115 “ Z pamiętnika kapitana austryackiego Pecka. (Przyczynek do dziejów powstania polskiego w r. 1831) [From the Momoir of An Austrian Captain Named Peck. (A Contribution to the History of the Polish Uprising of 1831)]," ed. Grzegorz Smólski, Przeglad Historyczny 5 (1907), 2: 221.

${ }^{116}$ KUCZYŃSKI, RuSSOCKI, and Willaume, Godło, barwy i hymn Rzeczypospolitej, 178.

${ }^{117}$ Powstanie styczniowe w zbiorach Muzeum Wojska Polskiego, 110-112.

${ }^{118}$ Orzet - znak żolnierza polskiego (The Eagle — the Sign of the Polish Soldier), ed. Antoni R. Chodyński (Malbork: Muzeum Zamkowe w Malborku, 1981-1983), 96.
} 
ards dating from that period were also supplied with similar mottos. On a flag with an identical three-field coat of arms that is in the collection of the Polish Army Museum there is the motto: WOLNOŚĆ CAŁOŚĆ NIEPODLEGŁOŚĆ (Freedom Integrity Independence), and on another one, which, during the uprising, belonged to Fr. Antoni Mackiewicz's unit, BOŻE ZBAW POLSKE (God, Save Poland). ${ }^{119}$ The standard of Gen. Edmund Różycki’s Volhynia Cavalry Regiment on its main side has the inscription: ZA WASZA I NASZA WOLNOŚĆ (For Your Freedom and Ours), and on the reverse side in the Ruthenian language, written in the Cyrillic script: ZA WOLJU RUSI, POLŠÈI I LYTWY. ${ }^{120}$

The Poles' war effort made during World War I and after led to the establishment of the Second Republic of Poland, and resulted in the formation of numerous units that had their own flags and standards. The mottos put on them were doubtlessly supposed to influence the attitudes of soldiers fighting under them. At the same time, they were a testimony to the ideological convictions of the people, groups and social circles on whose initiative they were funded. Designing and producing them took place in all kinds of conditions and circumstances, which was reflected in the varying contents of the images and inscriptions put on them. As an example, the vexilla of Greater Poland units that were formed starting in December 1918 may be mentioned. On the flag of the $1^{\text {st }}$ Sredzka Company that was funded by the local society there was the motto BOŻE, BŁOGOSŁAW NAM (God, Bless Us). Soon afterwards, the inscriptions placed on the military standards of particular regiments of the Greater Poland Army were defined in the orders of the day $\mathrm{Nr}$ 89 and 90 of the Headquarters of $3^{\text {rd }}-4^{\text {th }}$ April 1919.

Because of the great variety of these mottos it is worth reviewing them. On the flag of the $2^{\text {nd }}$ Regiment of Greater Poland Rifles there was: $\mathrm{Z}$ BOGIEM ZA OJCZYZNE (With God for the Homeland); on the flag of the $3^{\text {rd }}$ Regiment of Greater Poland Rifles: ŻYCIE, TRUD I MIENIE ZA PRAWO I WOLNOŚĆ OJCZYZNY (Life, Hardship and Property for the Law and Freedom of the Homeland); of the $6^{\text {th }}$ Regiment of Greater Poland Rifles: MOCA BÓG CELEM OJCZYZNA (God Is the Power, Homeland Is the Aim); of the $7^{\text {th }}$ Regiment of Greater Poland Rifles: OJCZYZNE, WOLNOŚĆ ZACHOWAJ NAM PANIE (Lord, Preserve the Homeland and Freedom for Us); of the $9^{\text {th }}$ Regiment of Greater

\footnotetext{
${ }^{119}$ Powstanie styczniowe w zbiorach Muzeum Wojska Polskiego, 112-117.

${ }^{120}$ Irena GRABOWSKA, "Pamiątki po generale Edmundzie Różyckim dowódcy jazdy wołyńskiej w r. 1863 [Mementoes of General Edmund Różycki, the Commander of Volhynia Cavalry in 1863]," in Powstanie niespetnionych nadziei 1863 [The Uprising of Unfulfilled Hopes] (Kraków: Krajowa Agencja Wydawnicza, 1984), 20-21 (Arsenał Polski).
} 
Poland Rifles: KU CHWALE OJCZYZNY (For the Glory of the Homeland); of the $11^{\text {th }}$ Regiment of Greater Poland Rifles: ZA WIARE I OJCZYZNE (For Faith and Homeland); of the $12^{\text {th }}$ Regiment of Greater Poland Rifles: ZA WOLNOŚĆ I NIEPODLEGŁOŚĆ (For Freedom and Independence); of the $1^{\text {st }}$ Poznan Garrison Regiment: Z BOGIEM W SERCU, Z BRONIĄ W RĘKU WOBEC WROGA OJCZYZNY BEZ LĘKU (With God in our Heart, With a Weapon in Hand, Without Fear of the Enemy of the Homeland). In turn, the $1^{\text {st }}$ Greater Poland Engineering Battalion received a flag with the motto: TAK NAM DOPOMÓŻ BÓG (So Help Us God), whereas cavalry regiments had standards with the inscriptions: KU CHWALE OJCZYZNY (For the Glory of the Country - the $1^{\text {st }}$ Greater Poland Uhlan Regiment); BIAŁY SZTANDAR WZNIOSŁE CZYNY (A White Standard - Lofty Deeds) (the $2^{\text {nd }}$ Greater Poland Uhlan Regiment); POD TWOJĄ OBRONĘ ... (Beneath Thy Protection - the $1^{\text {st }}$ Greater Poland Volunteer Cavalry Regiment); POD TWOJĄ OBRONĘ UCIEKAMY SIĘ (Beneath Thy Protection We Take Refuge - the $3^{\text {rd }}$ Uhlan Regiment, the $7^{\text {th }}$ Horse Rifle Regiment).

No less lofty mottos, albeit lacking religious elements, were put on the flag sheets of regiments formed in Pomerania. Their wording was as follows: WSPÓLNA MOC TYLKO ZDOŁA NAS OCALIĆ (Only Joint Power Will Be Able To Save Us - the Torun Rifle Regiment), ZA HONOR NARODU, ZA WIELKOŚĆ OJCZYZNY (For the Nation's Honor, For the Homeland's Greatness - the Grudziądz Rifle Regiment), AŻ DO OSTATNIEJ KROPLI KRWI (To the Last Drop of Blood - the Starogard Rifle Regiment), PONAD ŻYCIE, PONAD ŚMIERĆ, PONAD SIEBIE SAMYCH (Above Life, Above Death, Above Ourselves - the Kashubia Rifle Regiment). ${ }^{121}$ The military standards of the Silesian insurgents also had inscriptions, e.g. the flag of the Volunteer Company of Ostropa that was part of the $1^{\text {st }}$ Battalion of the $4^{\text {th }}$ Regiment of Gliwice Insurgents on its main side beside the White Eagle had the words ZA WIARE, WOLNOŚĆ I OJCZYZNĘ (For Faith, Freedom and Homeland), and on the reverse side, along with the image of the Black Madonna of Częstochowa, POD TWOJĄ OBRONĘ UCIEKAMY SIĘ. ${ }^{122}$

The Polish Army units that were formed in the period of the regaining of independence were to receive uniform standards (cavalry) and flags (infantry), according to the regulations of the Law of $1^{\text {st }}$ August 1919. The Law provided for the motto HONOR I OJCZYZNA (Honor and Homeland) placed in

\footnotetext{
${ }^{121}$ Jarosław ŁUCZAK, "Choragwie i sztandary Wojsk Wielkopolskich [Flags and Standards of the Greater Poland Military]." Studia do Dziejów Dawnego Uzbrojenia i Ubioru Wojskowego 8 (1982): 114-122.

${ }^{122}$ Orzet Biaty - 700 lat, catalogue item IX.30 and Fig. 196.
} 
the laurel wreath in the center of the Knight's Cross on the left side of the sheet of this kind of military standards. ${ }^{123}$ However, the introduction of regulation flags and standards in the Polish Army was a long process. As a result, numerous formations used irregular vexilla, which was especially common in the earliest period of the existence of the Second Republic of Poland. Among such formations was the $1^{\text {st }}$ Chevau-léger Regiment that had on its standard the image of Our Lady of the Gate of Dawn and the inscription: TUUM FAC NEC RESPICIES FINEM [Do What Rests With You Without Looking at the Results]. On the military standard given to the $6^{\text {th }}$ Uhlan Regiment (Kaniow Uhlan Regiment) under the image of Mother of God was placed the invocation: POD TWOJĄ OBRONE. The $7^{\text {th }}$ Uhlan Regiment of Mińsk Mazowiecki had a standard with the image of the Lord Jesus on the left side and the inscription: OTO SERCE, KTÓRE NAS TAK BARDZO UMIŁOWAŁO (This Is the Heart that Loves Us So Much). In turn, the standard of the $12^{\text {th }}$ Podolian Uhlan Regiment was supplied with the motto Z BOGIEM ZA OJCZYZNE (With God for Homeland). ${ }^{124}$ The $17^{\text {th }}$ Infantry Regiment, that in the interwar period was stationed in Rzeszów, also had an irregular flag. On the right side of the sheet, under the image of the Black Madonna of Częstochowa there was the devout invocation POD TWOJA OBRONE, and on the left side, under the silhouette of the White Eagle, there was the sentence W JEDNOŚCI SIŁA (The Strength Is In Unity). ${ }^{125}$

World War II brought the need of creating new vexilla, whose appearance did not always match the regulations from the interwar period. This also concerned the inscriptions of the motto type, sometimes far from the motto HONOR I OJCZYZNA (Honor and Homeland) that had been used before. On $15^{\text {th }}$ October 1943 it was officially changed by adding the word BÓG (God) at the beginning. ${ }^{126}$ This was reflected in the appearance of standards made for the formation of the Polish Armed Forces in the West. One example is the military standard of the $8^{\text {th }}$ Carpathian Rifle Battalion in the $3^{\text {rd }}$ Carpathian Rifle Division funded by the inhabitants of the Italian towns of Imola and Senigalia in 1946, having on its reverse side in the middle of the Knight's Cross the inscription BOG HONOR I OJCZYZNA (God Honor and Homeland).

It is worth noting that some of those formations received standards with

\footnotetext{
${ }^{123}$ KUKAWSKI, "Sztandary," 20.

124 GEPNER, "Sztandary,” 247-250.

${ }^{125}$ SATORA, Kazimierz. Opowieści wrześniowych sztandarów, 54 and Fig. 103 and 104.

${ }^{126}$ The Official Journal of Commander-in-Chief and Ministry of Defence, 1943, Nr 6, par. 61: In Art. 10 p. 3 of the Decree of the President of the Republic of Poland of $24^{\text {th }}$ November 1937 on military standards and Ministry of War "before the word Honor the word Bóg is added".
} 
very unusual mottos on them. The famous standard of the airmen in Great Britain should be mentioned here, that had on its reverse side the motto MIŁOŚĆ ŻĄDA OFIARY (Love Demands Sacrifice) ${ }^{127}$, and also the standard of the Independent Parachute Brigade with the inscription BÓG I OJCZYZNA on its main side, and on the reverse one SURGE POLONIA. ${ }^{128}$ They both were made, as was mentioned above, in occupied Poland and secretly transferred to the West. The military standard of the $13^{\text {th }}$ Battalion of Wilno Rifles "Rysie" that was a part of the $5^{\text {th }}$ Wilno Infantry Brigade, made by the Polish community in Teheran in 1943, besides the typical motto of the interwar period HONOR I OJCZYZNA on its right side, also had the invocation POD TWOJA OBRONE UCIEKAMY SIE together with the image of Our Lady of the Gate of Dawn on its left side. ${ }^{129}$ An unusual motto appeared on the standard of the $8^{\text {th }}$ Battalion of the Brabant Rifles of the $1^{\text {st }}$ Armored Division that was funded after the war by the inhabitants of Breda. It was formulated in Dutch (DEN VADERLAND GETROUVE, that is: Faithful to Homeland) and placed on the ribbon fastened to the flagpole. ${ }^{130}$

A great variety of contents is presented by the mottos placed on the standards and pennants owned by the clandestine and guerilla formations in the occupied Polish territories. Some of them were similar to the ones used in the Polish Army, but some differed from them completely. On the standard of the unit of the Home Army from Rzeczyca is found the motto BóG I OJCZYZNA, and the same words may be seen on the flag sheet of the $5^{\text {th }}$ Sub-district of the Warsaw District of the Home Army; however, on its reverse side there are also others: WOLNOŚĆ NIEPODLEGŁOŚĆ (Freedom Independence). Several military standards were supplied with the motto BÓG HONOR I OJCZYZNA, an example being the standard of the sabotage unit in the Skierniewice District of the Home Army ${ }^{131}$, but sometimes beside them also other slogans were placed, like a fragment of an old patriotic song, e.g. ORLE POWSTAŃ Z WIĘZÓW RAN ORLE WZLEĆ NAD POLSKI ŁAN (Eagle, Rise From the Wounds of Ties, Eagle, Fly Over the Polish Field) on the standard

\footnotetext{
${ }^{127}$ B. MORYC, "Miłość żąda ofiary - hasło z lotniczego sztandaru [Love Demands Sacrifice - A Motto from the Airforce Standard], Wiraże 1967, No. 1, p. 10; Murgrabia, Symbole wojskowe, 38; Andrzej R. JANCZAK, Miłość żada ofiary. Relikwia „,Katoczka” kpt. pil.-obs. Jana III Hryniewicza - Sztandar Polskich Sit Powietrznych w Wielkiej Brytanii 1940-1992 [Love Demands Sacrifice. Captain Pilot Jan III Hriniewicz's Relic "Katoczka"- the Standard of the Polish Airforce in Great Britain 1940-1992] (Warszawa: [s.n], 1992).

${ }^{128}$ Murgrabia, Symbole wojskowe, 39.

${ }^{129}$ Ibid., 45.

${ }^{130}$ Ibid., 42.

${ }^{131}$ Ney-Krwawicz, SiemaszKo, and SiemaSZKo, Bojowe sztandary i proporce, 26-28.
} 
of the Northern Quarter of the Lvov-Town Inspectorate of the Home Army) ${ }^{132}$, or the motto ŻYCIE DLA NARODU (Our Life for the Nation) on the standard of the $1^{\text {st }}$ Bolesław Chrobry Armored Regiment formed in Vilnius. ${ }^{133}$

Inscriptions with religious contents appeared on vexilla fairly frequently in those times. The standard of the "Grunwald" Platoon of the $14^{\text {th }}$ Uhlan Regiment had on its sheet the words BŁOGOSŁAW MATKO NASZEJ POLSKIEJ ZIEMI (Mother, Bless Our Polish Land). The invocation on the reverse side of the standard of the guerilla unit of the $1^{\text {st }}$ Battalion of the $35^{\text {th }}$ Infantry Regiment of the Home Army was also directed to the Mother of God: KRÓLOWAŁAŚ W POKOJU BRONIŁAŚ W NIEWOLI CHROŃ NAS I TERAZ W NASZEJ CIĘŻKIEJ NIEdoli (You Reigned In Peace Time, Defended Us In Our Bondage, Protect Us Also Now In Our Deep Misery) (at the same time on the main side there was the motto: ZA NASZĄ WOLNOŚĆ I WASZA); and similarly, on the military standards of other guerilla formations of the Home Army: of the "Błyskawica" unit (KRÓLOWO KORONY POLSKIEJ MIEJ NAS W SWEJ OPIECE - Queen of the Polish Crown, Keep Us Under Your Protection); of the $27^{\text {th }}$ Infantry Regiment of the Home Army and of the "Kmicic" unit in the Vilnius Region: KRÓLOWO KORONY POLSKIEJ MÓDL SIĘ ZA NAMI (Queen of the Polish Crown, Pray For Us); or of the abovementioned Self-Defense Center Przebraże: KRÓLOWO KORONY POLSKIEJ BŁOGOSŁAW LUDOWI TWOJEMU (Queen of the Polish Crown, Bless Your People). It is worth adding that on the latter vexilium there was also a fragment of M. Konopnicka's poem "Rota" ("The Oath"): NIE RZUCIM ZIEMI SKĄD NASZ RÓD (We Won't Forsake the Land We Came From). ${ }^{134}$ Sometimes apostrophes of this type were also directed to saints, which may be seen on the standard of the $22^{\text {nd }}$ Infantry Regiment of the AK that was made in 1945, after the Russians had entered the Polish territories, on whose reverse side the words appeared: SW. JADWIGO KRÓLOWO UPROŚ U BOGA SWOJĄ PRZYCZYNĄ NIECH POLSKE KLĘSKI OMINĄ (St Hedwig, Queen of Poland, With Your Prayer Beg God Into Making Defeats Pass By Poland). ${ }^{135}$

The mottos placed on the military standards made from 1943 for the formations which were part of the Polish People's Army were also quite far from uniform. The earliest item in this group, that is, the standard of the $1^{\text {st }}$ Tadeusz Kościuszko Infantry Division, had on the left side of its sheet,

132 Ibid., 34-37.

${ }^{133}$ NEY-KRWAWICZ, Sztandary i proporce, 51-52.

${ }^{134}$ NeY-KRWAwiCZ, SiEMASZKo, and SiEMASZKO, Bojowe sztandary i proporce, 38-41, 48-51, 56-59, 60-63, 96-99.

${ }^{135}$ NeY-Krwawicz, Sztandary i proporce, 138 and Fig. 63. 
which was the main side, the image of the White Eagle and the inscription HONOR I OJCZYZNA, and on the right side the words ZA NASZA WOLNOŚĆ I WASZA placed in the form of a semicircle around the bust of Tadeusz Kościuszko. On the standard of the $2^{\text {nd }} J$. H. Dąbrowski Warsaw Infantry Division the mottos HONOR I OJCZYZNA and ZA NASZĄ I WASZĄ WOLNOŚĆ were placed on the left side of the sheet. ${ }^{136}$

In this period these were the most frequently seen mottos, but on some vexilla funded by local communities sometimes inscriptions occurred with a different content. As an example the standard of the $9^{\text {th }}$ Drezdeńska Infantry Division may be mentioned that had the inscription BÓG I OJCZYZNA; the standard was given to this formation in 1944 by the inhabitants of Białystok $^{137}$, the standard of the $1^{\text {st }}$ Warsaw Sapper Brigade funded by the inhabitants of Zielonka in January 1945, with the motto BÓG HONOR I OJCZYZNA, or standards of other sapper formations (the $1^{\text {st }}$ Warsaw Sapper Brigade, the $21^{\text {st }}$ Sapper Battalion, the $30^{\text {th }}$ Sapper Battalion) with the pious apostrophe POD TWOJĄ OBRONĘ UCIEKAMY SIĘ placed beside the images of the Black Madonna of Częstochowa. ${ }^{138}$ As can be seen, the Communist authorities at that time still tolerated the reflection of traditional religious and national values on standards whose appearance was, to a large degree, designed by the funders themselves.

With time, this situation changed. In the post-war period the Polish People's Army twice received new patterns of vexilla that were made according to the regulations. The regimental standard, according to the regulations introduced in 1946, on both sides of the sheet had the so-called Cross of Grunwald, on which, on the right side beside the White Eagle, there was the motto HONOR I OJCZYZNA, and on the left side ZA POLSKE, WOLNOŚĆ I LUD (For Poland, Freedom and the People). The next changes promulgated in 1955 on the reverse side of the military standard introduced the inscription: ZA NASZĄ OJCZYZNĘ POLSKA RZECZPOSPOLITĄ LUDOWA (For Our Polish People's Republic Homeland).

\footnotetext{
${ }^{136}$ Bigoszewska and Wiewióra, Sztandary Ludowego Wojska Polskiego, 13-16.

${ }^{137}$ Ibid., 18-20.

${ }^{138}$ Wojsko Polskie. Krótki informator historyczny o Wojsku Polskim w latach II wojny światowej [The Polish Army. A Short Historical Guide on the Polish Army in the Years of II World War], vol. 4: Juliusz J. MAlCZEwSKI and Roman L. POLKOwSKI, Regularne jednostki ludowego Wojska Polskiego: formowanie, działania bojowe, organizacja, uzbrojenie, metryki jednostek inżynieryjno-saperskich drogowych $i$ chemicznych [Regular Units of the Polish People's Army: Formation, Military Actions, Organization, Armament, Regulations of the Engineering-Sapper, Road and Chemical Units] (Warszawa: Wydawnictwo Ministerstwa Obrony Narodowej, 1970), $138,155,175,182$.
} 
The political changes started in 1989 made it also possible to depart from the Communist heritage in the sphere of the appearance of military standards. There was no doubt that those defined did not correspond to the rules of the new political system or to the expectations of society. Sometimes temporary solutions were introduced, which is shown by a letter written to the Editor-in-Chief of the daily "Życie Warszawy" after Lech Wałęsa was elected as the President of the Republic of Poland.

"It was with deep sorrow that I watched the President of the Republic of Poland Lech Wałęsa, when, taking over the command of the Armed Forces, he paid tribute to a strange standard. It is the standard of the Polish People's Army, to which a crown was added and the word "People's" removed. A linguistic absurdity resulted: "ZA NASZĄ OJCZYZNĘ POLSKĄ RZECZPOSPOLITĄ" ("For Our Polish Republic Homeland") (?!). [...] I understand the haste. What I do not understand is why any standard from the Museum of the Polish Army was not used.-Dr Zbigniew Wolak, Reserve Second Lieutenant of the Polish Armed Forces in Italy and Great Britain, a Home Army soldier. ${ }^{139}$

A new model of military standards legally binding at present was introduced by the Law of $19^{\text {th }}$ February 1993. According to its ruling, the appearance from the period of the Second Republic of Poland was restored to those objects, with the White Eagle in a crown, adopted in 1927, and the motto was given the wording adopted by the Polish Armed Forces in the West in 1943: BÓG HONOR OJCZYZNA. ${ }^{140}$

In principle, in the four groups suggested above all of the inscriptions may be included that are seen on the military standards used by Polish armed formations during the last few centuries. As has been shown, on one flag texts often appeared that could be included in different categories. In analyzing the phrases that are found on vexilla one always has to remember that the inscriptions most often occurred along with iconic and heraldic images, forming together with them an integral whole. The inscriptions themselves usually had significant contents, both the information they give and a the ideas they convey. They refer to the identity of the unit, its achievements and its services. They point to the most important events and episodes from its history which should be especially clearly commemorated, emphasised, and constantly reminded to all who look at the standard. Apart from that, the inscriptions of the motto type manifested the attachment of the soldiers serv-

\footnotetext{
${ }^{139}$ Quoted after: Puls 13 (1991), No. 2: 120-121; the photo showing the ceremony is presented in Newsweek (Polish edition) in its issue of $4^{\text {th }}$ September 2005: 70-71.

140 SZYMAŃSKI and ZAJĄC, Nasze sztandary, 25.
} 
ing under the standard to definite religious, national, state or moral values. An analysis of these type of phrases, even if they seem stereotypical, conventional and imposed by the authorities, may supply one with many important conclusions. Among others, it will make it possible to find out where the inspiration for formulating the mottos came from, what message was to be contained in them, or on what the army's morale was to be built. The flag inscriptions then become a rewarding field for research by experts from various domains.

\section{BIBLIOGRAPHY}

BigoszewsKA, Wanda. "Proporzec z 1831 r. świadectwem genezy hasła 'Za naszą i waszą wolność" [The 1831 Pennant As a Testimony of the Origin of the Motto "For Our Freedom and Yours." In Muzealnictwo Wojskowe [Military Museology]. Vol. 4, edited by Muzeum Wojska Polskiego [Polish Army Museum], 316-326. Warszawa: Wydawnictwo Ministerstwa Obrony Narodowej 1989.

Bigoszewska, Wanda, and Henryk Wiewióra. Sztandary Ludowego Wojska Polskiego 1943 1974 [Standards of the Polish People's Army 1943-1974]. Warszawa: Wydawnictwo Ministerstwa Obrony Narodowej, 1974.

BigoszewsKa, Wanda, and Maria Halina SŁoniewskA. "Chorągwie i sztandary z lat 1815-1831 w zbiorach Muzeum Wojska Polskiego [Flags and Standards of the Years 1815-1831 in the Polish Army Museum Collections]." In Muzealnictwo Wojskowe [Military Museology]. Vol. 3, edited by Muzeum Wojska Polskiego [Polish Army Museum], 279-301. Warszawa: Wydawnictwo Ministerstwa Obrony Narodowej, 1985.

BRÜCKNER, Aleksander. Encyklopedia staropolska. Vol. 3. Warszawa: Nakładem Księgarni Trzaski, Everta i Michalskiego, 1939.

BrZeziński, Richard. Polish Armies 1569-1696 (1). Men at Arms Series. London: Osprey Publishing, 1987.

CZAPLIŃski, Władysław. Władysław IV i jego czasy [Władysław IV Vasa and His Times]. Warszawa: Wiedza Powszechna, 1972.

Encyklopedia wojskowa (Military Encyclopedia). Vol. 1, edited by Otto Laskowski. Warszawa: Wydawnictwo Towarzystwa Wiedzy Wojskowej i Wojskowego Instytutu NaukowoWydawniczego, 1931.

GembarZewski, Bronisław. Żotnierz polski. Ubiór, uzbrojenie i oporzqdzenie [The Polish Soldier: Dress, Weaponry and Equipment]. Vol. 2-4. Warszawa: Wydawnictwo Ministerstwa Obrony Narodowej, 1962-1964.

GEPNER, Stanisław. "Sztandary [Standards]." In Księga jazdy polskiej [The Book of Polish Cavalry], edited by Bronisław Wieniawa-Długoszowski and Stanisław J. Haykowski, 240254. Warszawa: Zakłady Graficzne Instytutu Wydawniczego "Biblioteka Polska”, 1938.

GRABOWSKA, Irena. "Pamiątki po generale Edmundzie Różyckim dowódcy jazdy wołyńskiej w r. 1863 [Mementoes of General Edmund Różycki the Commander of Volhynia Cavalry in 1863]." In Powstanie niespetnionych nadziei 1863 [The Uprising of Unfulfilled Hopes]. Kraków: Krajowa Agencja Wydawnicza, 1984. 
GRABOWSKI, Waldemar. "Polskie choragwie z XVI-XVIII wieku w zbiorach ikonograficznych Armemuseum w Sztokholmie [Polish Flags of the $16^{\text {th }}-18^{\text {th }}$ Centuries in the Iconographic Collection of the Armemuseum in Stockholm]." Dawna Broń i Barwa 16 (2001), No. 23: 3-30.

KuczyŃski, Stefan K., Stanisław Russocki, and Juliusz Willaume. Godto, barwy i hymn Rzeczypospolitej. Zarys dziejów [The Emblem, Colors and Anthem of the Republic of Poland: An Outline of the History]. $3^{\text {rd }}$ ed. Warszawa: Wiedza Powszechna, 1978.

KuKawski, Lesław. "Sztandary [Standards]." In Broń i barwa Wojska Polskiego w roku 1939. (Informator wystawy) [The Polish Army's Weaponry and Colors in 1939. (Exhibition Guide)]. Lublin 1993.

ŁUCZAK, Jarosław. "Choragwie i sztandary Wojsk Wielkopolskich [Flags and Standards of the Greater Poland Military]." Studia do Dziejów Dawnego Uzbrojenia i Ubioru Wojskowego, 8 (1982): 103-123.

Murgrabia, Jerzy. Symbole wojskowe Polskich Sit Zbrojnych na Zachodzie 1939-1945 [Military Symbols of the Polish Armed Forces in the West 1939-1945]. Warszawa: Wydawnictwo Bellona, 1990.

Muzeum Wojska Polskiego w Warszawie. Katalog zbiorów. Wiek XVII [The Polish Army Museum in Warsaw: A Catalogue of the Collections. The $17^{\text {th }}$ Century], edited by Zofia Stefańska and Zygmunt Gamski. Warszawa: Wydawnictwo Ministerstwa Obrony Narodowej, 1968.

Muzeum Wojska Polskiego w Warszawie. Katalog zbiorów. Wiek XVIII [The Polish Army Museum in Warsaw: A Catalogue of the Collections. The $18^{\text {th }}$ Century], edited by Zofia Stefanska, Jan Benda, Alfred Funkiewicz, Maria Rohozińska, and Józef Zalewski. Warszawa: Wydawnictwo Ministerstwa Obrony Narodowej, 1960.

Ney-Krwawicz, Marek, Zbyszko SiemaszKo, and Maciej SiemaszKo. Bojowe sztandary i proporce Armii Krajowej [The Home Army's Combat Standards and Pennants]. Warszawa: Krajowa Agencja Wydawnicza, 1991.

NEY-KRWAWICZ, Marek. Sztandary i proporce Armii Krajowej [The Home Army's Standards and Pennants]. Warszawa: Semper, 1994.

Orzet Bialy - 700 lat herbu Państwa Polskiego [The White Eagle — 700 Years of the Emblem of the Polish State]. Warszawa: Zamek Królewski, 1995.

Orzel-znak żotnierza polskiego [The Eagle - the Sign of the Polish Soldier], edited by Antoni R. Chodyński. Malbork: Muzeum Zamkowe w Malborku, 1981-1983.

Pelc, Janusz. Barok - epoka przeciwieństw [Baroque - an Epoch of Contrasts]. Warszawa: Czytelnik, 1993.

Polska. Dzieje cywilizacji i narodu [Poland, History of the Civilization and the Nation]. Vol. 4: Rzeczpospolita szlachecka 1586-1795 [The Noblemen's Republic 1586-1795], edited by Marek Derwich. Warszawa-Wrocław: Ossolineum, 2003.

Powstanie styczniowe w zbiorach Muzeum Wojska Polskiego [The January Uprising in the Polish Army Museum Collection], edited by Wanda Bigoszewska and Maria Halina Słoniewska. Warszawa: Wydawnictwo Ministerstwa Obrony Narodowej, 1966.

Satora, Kazimierz. Opowieści wrześniowych sztandarów [Tales of the September Standards]. Warszawa: Instytut Wydawniczy Pax, 1990.

Stahr, Maria. Medale Wazów w Polsce 1587-1668 [The Vasas' Medals in Poland 1587-1668]. Wrocław: Ossolineum 1990.

SZYMAŃSKI, Jan, and Stanisław ZAJĄC. Nasze sztandary. Kraków: Instytut Teologiczny Księży Misjonarzy, 1998. 
WiELECKI, Henryk. "Choragwie i sztandary w zbiorach Muzeum Wojska Polskiego [Flags and Standards in the Polish Army Museum Collection]." In Muzealnictwo Wojskowe [Military Museology]. Vol. 7, edited by Muzeum Wojska Polskiego [Polish Army Museum], 319350. Warszawa: Wydawnictwo Ministerstwa Obrony Narodowej, 2000.

Wojsko Polskie. Krótki informator historyczny o Wojsku Polskim w latach II wojny światowej [The Polish Army. A Short Historical Guide on the Polish Army in the Years of II World War], vol. 4: Juliusz J. MALCZEWSKI and Roman L. POLKOWSKI, Regularne jednostki ludowego Wojska Polskiego: formowanie, działania bojowe, organizacja, uzbrojenie, metryki jednostek inżynieryjno-saperskich drogowych i chemicznych [Regular Units of the Polish People's Army: Formation, Military Actions, Organization, Armament, Regulations of the Engineering-Sapper, Road and Chemical Units]. Warszawa: Wydawnictwo Ministerstwa Obrony Narodowej, 1970.

ZnAMIEROWSKI, Alfred. Stworzony do chwaty [Made for Glory]. Warszawa: Editions Spotkania, 1993.

\section{INSCRIPTIONS ON MILITARY FLAGS IN POLAND: AN ATTEMPT AT FORMING A TYPOLOGY}

\section{S u m m a ry}

This article is an attempt at systematizing the body of inscriptions that accompanied the heraldic and iconographic inscriptions on Polish military flags and standards in the course of past centuries. It presents the suggestion of dividing them into four groups. The first comprises property inscriptions, giving information about who the flag belonged to, who its owner was or who used it. In the second group are inscriptions called 'funding' ones; they contain data referring to the funders or makers of those objects. Commemorative inscriptions were included in group three; they commemorated important events connected with the history of the unit or with its tradition. The fourth group consists of inscriptions in the form of sentences, mottos or apostrophes, usually having a lofty and solemn character. In practice, inscriptions belonging to different groups often appear side by side on the same flag. Usually they contain important information and ideological content.

Key words: vexillology; Polish Army; flags; standards; inscriptions.

Translated from Polish by Tadeusz Karlowicz

The preparation of the English version of Roczniki Humanistyczne and its publication in electronic databases was financed under contract no. 836/P-DUN/2018 from the resources of the Minister of Science and Higher Education for the popularization of science. 